\title{
Gene expression profiling reveals effects of Cimicifuga racemosa (L.) NUTT. (black cohosh) on the estrogen receptor positive human breast cancer cell line MCF-7 \\ Friedemann Gaube ${ }^{1}$, Stefan Wolfl2,3, Larissa Pusch ${ }^{2}$, Torsten C Kroll ${ }^{2}$ and Matthias Hamburger*1,4
}

\begin{abstract}
Address: ${ }^{1}$ Institute of Pharmacy, Department of Pharmaceutical Biology, University of Jena, Semmelweisstr. 10, 07743 Jena, Germany, ${ }^{2}$ Clinic of Internal Medicine II, University of Jena, Erlanger Allee 101, 07747 Jena, Germany, ${ }^{3}$ Institute of Pharmacy and Molecular Biotechnology, University of Heidelberg, Im Neuenheimerfeld 364, 69120 Heidelberg, Germany and ${ }^{4}$ Department of Pharmaceutical Sciences, Institute of Pharmaceutical Biology, University of Basel, Klingelbergstr. 50, CH-4053 Basel, Switzerland

Email: Friedemann Gaube - Friedemann.Gaube@uni-jena.de; Stefan Wolfl - wolfl@uni-hd.de; Larissa Pusch - Larissa.Pusch@mti.uni-jena.de; Torsten C Kroll - Torsten.Kroll@med.uni-jena.de; Matthias Hamburger* - matthias.hamburger@unibas.ch

* Corresponding author
\end{abstract}

Published: 20 September 2007

BMC Pharmacology 2007, 7:1 I doi:10.1186/147|-2210-7-11
Received: 25 January 2007

Accepted: 20 September 2007

This article is available from: http://www.biomedcentral.com/ |47/-22/0/7// I

(c) 2007 Gaube et al; licensee BioMed Central Ltd.

This is an Open Access article distributed under the terms of the Creative Commons Attribution License (http://creativecommons.org/licenses/by/2.0), which permits unrestricted use, distribution, and reproduction in any medium, provided the original work is properly cited.

\begin{abstract}
Background: Extracts from the rhizome of Cimicifuga racemosa (black cohosh) are increasingly popular as herbal alternative to hormone replacement therapy (HRT) for the alleviation of postmenopausal disorders. However, the molecular mode of action and the active principles are presently not clear. Previously published data have been largely contradictory. We, therefore, investigated the effects of a lipophilic black cohosh rhizome extract and cycloartane-type triterpenoids on the estrogen receptor positive human breast cancer cell line MCF-7.
\end{abstract}

Results: Both extract and purified compounds clearly inhibited cellular proliferation. Gene expression profiling with the extract allowed us to identify 43I regulated genes with high significance. The extract induced expression pattern differed from those of $17 \beta$-estradiol or the estrogen receptor antagonist tamoxifen. We observed a significant enrichment of genes in an antiproliferative and apoptosis-sensitizing manner, as well as an increase of mRNAs coding for gene products involved in several stress response pathways. These functional groups were highly overrepresented among all regulated genes. Also several transcripts coding for oxidoreductases were induced, as for example the cytochrome $\mathrm{P} 450$ family members IAI and IBI. In addition, some transcripts associated with antitumor but also tumor-promoting activity were regulated. Real-Time RT-PCR analysis of 13 selected genes was conducted after treatment with purified compounds the cycloartane-type triterpene glycoside actein and triterpene aglycons - showing similar expression levels compared to the extract.

Conclusion: No estrogenic but antiproliferative and proapoptotic gene expression was shown for black cohosh in MCF-7 cells at the transcriptional level. The effects may be results of the activation of different pathways. The cycloartane glycosides and - for the first time - their aglycons could be identified as an active principle in black cohosh. 


\section{Background}

Cimicifuga racemosa (L.) NUTT. (syn. Actaea racemosa; black cohosh, family Ranunculaceae) is a North American perennial herb which has been traditionally used by Native Americans for the treatment of rheumatism, dyspepsia, epilepsy, kidney ailments, dysmenorrhoea and the relief of pain during menses and childbirth $[1,2]$. Since the 1950s, phytopharmaceuticals containing black cohosh extracts from the rhizome are used for the alleviation of menopausal disorders [3]. Since the Women's Health Initiative (WHI) described adverse effects of hormone replacement therapy (HRT) such as increased risk of breast cancer and cardiovascular diseases [4], the popularity of herbal alternatives such as black cohosh has considerably increased.

The phytochemicals in black cohosh rhizomes have been well studied, and numerous cycloartane-type triterpene glycosides (e.g. actein Figure 1), aromatic acids (e.g. caffeic and ferulic acid), cinnamic acid esters (e.g. fukinolic acid, cimicifugic acids) and various minor compounds have been reported $[1,2,5]$. The pharmacology of rhizome extracts has been investigated, whereby most investigations addressed the effects on the hormonal (estrogenic) system. An estrogen-like activity was reported initially [6$8]$, but these effects could not be confirmed in later studies [8-11]. Subsequently, antiestrogenic properties were proposed on the basis of in vitro experiments $[8,12,13]$. Because a black cohosh extract influenced bone, endometrium and hypothalamus, but not uterus in a estrogen-like manner, it was postulated to contain compounds that act as selective estrogen receptor modulators (SERMs) and, therefore, to be different from common phytoestrogens - a presumption that is still a matter of dispute [14-17].

In binding studies black cohosh extracts showed no affinity to estrogen receptors $\alpha$ and $\beta(\mathrm{ER} \alpha / \beta)$, progesterone $(\mathrm{PR})$ or androgen receptor (AR) $[10,16,18,19]$, but weak

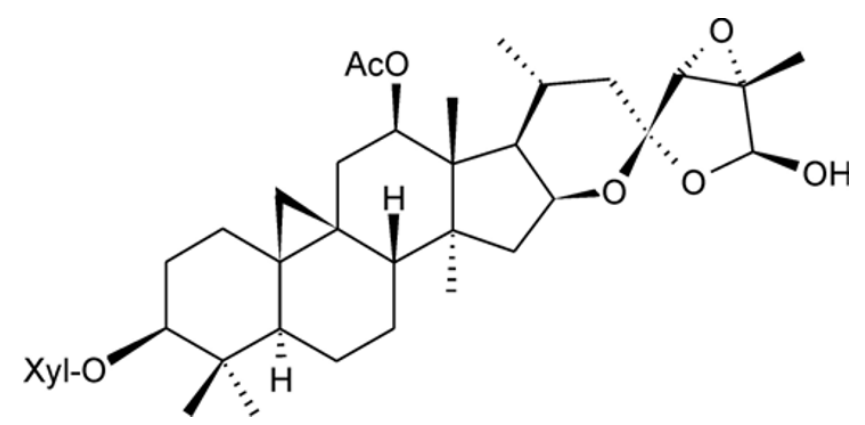

Figure I

Chemical structure of Actein, the major cycloartane-type triterpene glycoside of black cohosh. affinity towards the aryl hydrocarbon receptor (AhR) $[20,21]$. Most recently, treatment of human breast cancer MCF-7 cells with black cohosh extracts and with fractions containing cycloartane glycosides and cinnamic acid esters, respectively, resulted in antiproliferative effects and induction of apoptosis [22,23]. Incubation of MCF-7 cells with a fraction containing the cycloartane glycosides led to cell cycle arrest at the G1/S- and, to a lesser degree, at the G2/M-transition points, and treatment with actein affected expression levels of some proteins, such as p21, in a G1-arresting manner [24].

Finally, irrespective of the putative estrogenic activity recent investigations reporting dopaminergic $[16,25]$, serotoninergic [26,27] and opioidic action [28] of black cohosh extracts provide evidence, that the beneficial effects such as reduction of hot flashes may be due to neurotransmitter and CNS activity.

Despite all these studies, the mode of action of black cohosh extracts and the nature of the active principles are presently not clear.

A major limitation of all these studies was that they were always conducted in a very specific perspective, while other possible modes of action were ignored. With the emergence of microarrays as a mature technology observation of global drug effects at gene expression level has become possible. This led us to perform a genome-wide gene expression profiling experiment to measure global effects of black cohosh at the mRNA level. For the study we used the ER $\alpha$-positive human breast cancer cell line MCF-7, a widely used in vitro model for investigations of (anti)estrogenic effects and estrogen-dependent breast cancer. MCF-7 cells were treated with a lipophilic black cohosh extract. The rationale behind using this extract was that ligands for nuclear receptors such as the estrogen receptors are lipophilic molecules. Parallel experiments were carried out with $17 \beta$-estradiol (E2) and the estrogen receptor antagonist tamoxifen to compare expression profiles with these drugs. Gene expression was determined using whole-genome Affymetrix GeneChip ${ }^{\circledast}$ Human Genome U133 Plus 2.0 Array, which represents about 38500 genes. Microarray results for selected genes were confirmed by real-time RT-PCR analysis. This method was also used to analyze the effects of actein, the major cycloartane glycoside in the rhizomes, and a mixture of cycloartenol aglycons. The latter was prepared to mimic a likely enzymatic hydrolysis of the glycosides in the gastrointestinal tract prior to absorption.

\section{Methods \\ Extract}

Rhizomes of black cohosh (Cimicifugae racemosae rhizoma) were obtained from Caesar\&Loretz (Hilden, Ger- 
many, lot number 82044149). Powdered rhizome (0.5 mm particle size, $10 \mathrm{~g}$ ) were subjected to pressurized liquid extraction using an $\mathrm{ASE}^{\circledR} 200$ Accelerated Solvent Extractor (Dionex, Sunnyvale, CA) at 120 bar and $70^{\circ} \mathrm{C}$. After a preheating step ( $5 \mathrm{~min})$, the sample was defatted with petroleum ether ( $5 \mathrm{~min}$ ), followed by extraction with dichloromethane for $10 \mathrm{~min}$. Solutions were collected in different vials. The petroleum ether solution was discarded. After evaporation of the solvent, $350 \mathrm{mg}$ of dry dichloromethane extract was obtained.

\section{Compounds}

The mixture of cycloartenol aglycons was obtained as follows: A dichloromethane extract of black cohosh rhizome (2 $\mathrm{kg}$ ) was prepared by maceration at room temperature for $24 \mathrm{~h}$. The extract $(25.5 \mathrm{~g})$ was separated on a silica gel

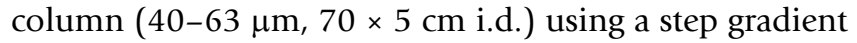
of $\mathrm{CHCl}_{3}-\mathrm{MeOH}-\mathrm{H}_{2} \mathrm{O}$ (90:9.5:0.5), $\mathrm{CHCl}_{3}-\mathrm{MeOH}-\mathrm{H}_{2} \mathrm{O}$ (70:30:3) and methanol. Fractions were combined on the basis of their TLC pattern. Fractions containing cycloartane glycosides were combined in equal proportions (250 mg each) and dissolved in methanol. After addition of 1 $\mathrm{N} \mathrm{HCl}$, the solution was refluxed for $1 \mathrm{~h}$. Aglycons were extracted by partitioning with chloroform. The chloroform extract was evaporated to dryness, and the residue (340 mg) was purified by chromatography on a Sephadex ${ }^{\circledast}$ LH20 (Pharmacia, Uppsala, Sweden) column, eluted with methanol to afford $120 \mathrm{mg}$ of aglycon mixture.

Actein was purchased from Phytoplan (Heidelberg, Germany), 17ß-estradiol from Sigma-Aldrich (Taufkirchen, Germany) and tamoxifen from MP Biomedicals (Eschwege, Germany).

For subsequent experiments extract and compounds were dissolved in dimethyl sulfoxide (DMSO) and diluted with appropriate assay media. The final concentration of DMSO did not exceed $0.1 \%$. This concentration was also used for control experiments.

\section{Cell culture}

The human breast adenocarcinoma cell line MCF-7 (obtained from ATCC) was routinely cultured in Dulbecco's Modified Eagle's Medium (DMEM) containing $10 \%$ fetal bovine serum (FBS) and Penicillin/Streptomycin $(100 \mathrm{U} / 100 \mu \mathrm{g} / \mathrm{ml})$ (Biochrom, Berlin, Germany) in a humidified incubator at $37^{\circ} \mathrm{C}$ and $5 \% \mathrm{CO}_{2}$. Before reaching confluence, cells were splitted every 3-4 days in a 1:4to 1:6-ratio. All experiments were performed with cells at passage numbers 25-33.

Hormone-free charcoal-dextran stripped serum (CSS) was prepared from FBS by agitating with $0.5 \%$ charcoal (Norit A) (Serva Feinbiochemica, Heidelberg, Germany) and $0.05 \%$ Dextran-T70 (Pharmacia) at $37^{\circ} \mathrm{C}$ for $60 \mathrm{~min}$.
After centrifugation at $3500 \mathrm{rpm}$ CSS was filter-sterilized $(0.22 \mu \mathrm{m})$ twice and stored at $-20^{\circ} \mathrm{C}$.

\section{Proliferation assay}

MCF-7 cells were seeded in 96-well microtitre plates (Greiner Bio-One, Frickenhausen, Germany) with a density of 3500 cells per well under culture conditions and incubated at $37^{\circ} \mathrm{C}$ and $5 \% \mathrm{CO}_{2}$. After 24 hours medium was removed, cells were washed with phosphate-buffered saline (PBS), and phenol red-free DMEM (Gibco ${ }^{\mathrm{TM}}$, Invitrogen, Karlsruhe, Germany) supplemented with 10\% CSS and test substances in concentrations indicated in the text were added. Medium was exchanged after 72 hours. After 120 hours cells were quantified by MTT assay $[29,30]$ as follows. Medium was removed and $100 \mu \mathrm{l}$ MTT (Fluka, Buchs, Switzerland), dissolved in phenol red-free DMEM at $0.5 \mathrm{mg} / \mathrm{ml}$, were added to each well. The plates were incubated at $37^{\circ} \mathrm{C}$ and $5 \% \mathrm{CO}_{2}$ for 4 hours. Formazan crystals were solubilized by addition of $100 \mu \mathrm{l}$ of $20 \%$ sodium dodecylsulfate (SDS) in $\mathrm{H}_{2} \mathrm{O}$ followed by incubation overnight at $37^{\circ} \mathrm{C}$. Optical density was measured at $544 \mathrm{~nm}$ using a microplate reader (Galaxy FluoStar, BMG Labtechnologies, Offenburg, Germany) with background substraction. Relative proliferation values were calculated as percentage of negative control $(0.1 \%$ DMSO value $=$ $100 \%)$. Experiments were repeated at least three times with 4 to 6 replicates per test concentration. The results are given as mean value \pm standard deviation (SD). Data were analyzed by Student's t-test. Statistically significance $v s$. DMSO control is represented as * $(\mathrm{p}<0.05),{ }^{* *}(\mathrm{p}<0.01)$ or $* * *(\mathrm{p}<0.001)$.

The acute cytotoxic potential of black cohosh extract, actein and the aglycons was determined with the Cytotoxicity Detection Kit (LDH) (Roche Diagnostics, Mannheim, Germany). No acute cytotoxicity could be found for the extract at concentrations of up to $70 \mu \mathrm{g} / \mathrm{ml}$, and up to $100 \mu \mathrm{M}$ for actein and the aglycons, respectively.

\section{RNA isolation}

MCF-7 cells were seeded in $75 \mathrm{~cm}^{2}$ culture flasks (Greiner Bio-One) at a density of 20000 cells $/ \mathrm{cm}^{2}$ under culture conditions and incubated at $37^{\circ} \mathrm{C}$ and $5 \% \mathrm{CO}_{2}$. After 20 hours medium was removed and cells were washed with PBS. Phenol red-free DMEM containing $10 \%$ CSS and $0.1 \%$ DMSO, $15 \mu \mathrm{g} / \mathrm{ml}$ black cohosh extract, $20 \mu \mathrm{M}$ actein, $30 \mu \mathrm{M}$ aglycons, $1 \mathrm{nM} 17 \beta$-estradiol or $10 \mu \mathrm{M}$ tamoxifen, respectively, were added. Cells were incubated for 24 hours at $37^{\circ} \mathrm{C}$ and $5 \% \mathrm{CO}_{2}$. Cells were washed twice with PBS and total RNA was extracted from cells using the RNeasy Mini Kit (Qiagen, Hilden, Germany) including on column DNase digestion according to the standard protocol. Quantity and purity of the obtained total RNA samples were determined by UV spectroscopy. RNA quality was controlled by gel electrophoresis on 
$1.5 \%$ agarose, stained with ethidium bromide $(1 \mu \mathrm{g} / \mathrm{ml})$. RNA was stored at $-80^{\circ} \mathrm{C}$ until use.

\section{Array hybridization}

Total RNA from each sample was labelled and hybridized to an Affymetrix GeneChip ${ }^{\circledR}$ Human Genome U133 Plus 2.0 array (Affymetrix, Santa Clara, CA) according to the manufacturer's protocol (manual version $700217 \mathrm{rev} 3$ ), with minor modification. Briefly, $5 \mu \mathrm{g}$ of total RNA was converted into cDNA by using the T7- $(\mathrm{dT})_{24}$ Primer (Affymetrix Inc), T4gp32 (USB Corporation, Cleveland, $\mathrm{OH}$ ) and the SuperScript II reverse transcriptase for cDNA synthesis (Invitrogen). Double-stranded cDNA was synthesized, cleaned and extracted with phenol/chloroform, followed by ethanol precipitation. Resulting CDNA was resuspended in $12 \mu \mathrm{l}$ RNase-free water. From the ds-cDNA template biotin-labeled cRNA was made with the Enzo High Yield RNA Transcript labeling kit (Enzo Diagnostics, Farmingdale, NY). The labeled cRNA was purified following the Qiagen RNeasy Clean up protocol (Qiagen) and concentrated to $24 \mu \mathrm{l}$ by ethanol precipitation. Fragmentation of the biotinylated cRNA $(20 \mu \mathrm{g})$ was done directly before hybridization to the microarray. Hybridizations and scanning were performed at the Affymetrix GeneChip Core facility of the Medical Faculty, University of Leipzig. On-chip labeling was done with phycoerythrin-conjugated streptavidin. After final washing steps fluorescence was detected with the Affymetrix GeneChip $30007 \mathrm{G}$ scanner.

\section{Primary data analysis}

Initial data analysis was performed using the Affymetrix Microarray Suite v5.1 software, setting the scaling of all probe sets to a constant value of 500 for each GeneChip. Because of the better implemented normalisation algorithm data were further normalized using RMA-Express software [31-33]. With RMAExpress all arrays were visually checked. There were no obvious failures on the chips. RMAExpress is using an enhanced quantile normalization [31,32]. All 8 experiments ( 4 different treatments - black cohosh extract, estradiol, tamoxifen and DMSO - in duplicate) were normalized together. Data were then exported to MS-Excel sheets. We used both the log as well as the natural output. All further comparisons and analyses are based on these RMAExpress outputs. Clearly regulated (= differentially expressed) genes were determined using the following criteria: (I) The signal intensity is higher than the median of all signal intensities on the array and (II) in both independent duplicate experiments the fold change vs. DMSO control is larger than 1.5.

\section{Real-time RT-PCR}

Expression levels of 14 selected genes were determined by a two step real-time RT-PCR using the LightCycler ${ }^{\circledR}$ system (Roche). Total RNA $(5 \mu \mathrm{g})$ from each sample was tran- scribed into cDNA with SuperScript III reverse transcriptase (Invitrogen) and a 1:1-mixture of random hexamers (Promega, Mannheim, Germany) and oligodT(20) primers (MWG Biotech, Ebersberg, Germany) following the standard protocol. Resulting cDNAs were diluted to a total volume of $100 \mu \mathrm{l}$ with water (PCRgrade). The reaction mixture for real-time PCR consisted

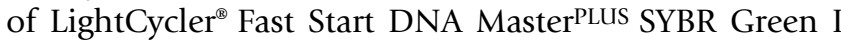
Master Mix (Roche), cDNA and 0,5 $\mu \mathrm{M}$ specific forward and reverse primers (MWG Biotech) for the genes listed in Table 1 . The protocol included an initial denaturation step at $95^{\circ} \mathrm{C}$ for $10 \mathrm{~min}$, followed by 5 cycles at $95^{\circ} \mathrm{C}$ for $5 \mathrm{~s}, 57^{\circ} \mathrm{C}$ for $10 \mathrm{~s}$ and $72^{\circ} \mathrm{C}$ for $17 \mathrm{~s}$ and finally 45 cycles at $95^{\circ} \mathrm{C}$ for $5 \mathrm{~s}, 59^{\circ} \mathrm{C}$ for $10 \mathrm{~s}$ and $72^{\circ} \mathrm{C}$ for $17 \mathrm{~s}$. Ratios between sample and control experiments were calculated after normalization of expression values to the housekeeping gene glyceraldehyde-3-phosphate dehydrogenase $(G A P D H)$. All RT-PCR expression values were determined at least three times from 2 independent biological experiments (treatments in duplicate). Data were analyzed by Student's t-test.

\section{Results \\ Proliferation assay}

We first performed a MTT-based proliferation assay to explore how the black cohosh extract and the selected compounds influence growth of MCF-7 cells. 17ß-estradiol, the positive control, significantly stimulated cell proliferation after $120 \mathrm{~h}$, reaching a plateau of maximal stimulation $(184.2 \pm 28.1 \%$ vs. DMSO control; $\mathrm{p}<0.001)$ at a concentration of $1 \mathrm{nM}$. The magnitude was comparable to effects observed in other studies with MCF-7 (ATCC) cells $[11,34,35]$. At a concentration of $10 \mu \mathrm{M}$ tamoxifen reduced cell proliferation to $45.7 \pm 6.8 \%$ (p < $0.001 v s$. DMSO control). Exposure of MCF-7 cells for 120 $\mathrm{h}$ to different concentrations of black cohosh extract, the cycloartane glycoside actein and the cycloartane aglycon mixture all inhibited cell proliferation in a dose-dependent manner (Figure 2). $\mathrm{IC}_{50}$ values - the concentrations that caused $50 \%$ inhibition of growth - were determined by extrapolation for black cohosh extract $(14.7 \pm 2.6 \mu \mathrm{g} /$ $\mathrm{ml})$, actein $(19.6 \pm 3.1 \mu \mathrm{M})$ and the aglycon mixture (30.3 $\pm 0.5 \mu \mathrm{M})$. These proliferation and cytotoxicity measurements provide only a preliminary information of biological activity.

\section{Gene expression microarray analysis with black cohosh extract}

General results

For gene expression profiling MCF-7 cells were treated with $15 \mu \mathrm{g} / \mathrm{ml}$ black cohosh extract, $1 \mathrm{nM} 17 \beta$-estradiol, $10 \mu \mathrm{M}$ tamoxifen or DMSO control for $24 \mathrm{~h}$ in the presence of $10 \%$ charcoal stripped serum. After RNA extraction, gene expression profiles were recorded using Affymetrix HG U133 Plus 2.0 GeneChip Arrays as 
Table I: Primers used for real-time RT-PCR

\begin{tabular}{|c|c|c|c|}
\hline Gene & & Primer Sequence 5'-3' & Product Size \\
\hline \multirow[t]{2}{*}{ Baculoviral IAP repeat-containing 5 (BIRC5) } & for & AAAGCATTCGTCCGGTTG & $152 \mathrm{bp}$ \\
\hline & rev & CCGCAGTTTCCTCAAATTCT & \\
\hline \multirow[t]{2}{*}{ Cyclin E2 (CCNE2) } & for & GACTGCTGCTGCCTTGTG & $151 \mathrm{bp}$ \\
\hline & rev & AAAAGTCTTCAGCTTCACTGGA & \\
\hline \multirow[t]{2}{*}{ Cyclin G2 (CCNG2) } & for & CCCAGAACCTCCACAACAG & $158 \mathrm{bp}$ \\
\hline & rev & GGTGCACTCTTGATCACTGG & \\
\hline \multirow[t]{2}{*}{ Cytochrome P450, family I, subfamily A, polypeptide I (CYPIAI) } & for & TCTTCGCTACCTACCCAACC & 196 bp \\
\hline & rev & ATCTGACAGCTGGACATTGG & \\
\hline \multirow[t]{2}{*}{ Cytochrome P450, family I, subfamily B, polypeptide I (CYPIBI) } & for & AGAACGTACCGGCCACTATC & 175 bp \\
\hline & rev & GGCTGGTCACCCATACAAG & \\
\hline \multirow[t]{2}{*}{ DNA-damage-inducible transcript 4 (DDIT4) } & for & GTTTGACCGCTCCACGAG & 166 bp \\
\hline & rev & CATCAGGTTGGCACACAAGT & \\
\hline \multirow[t]{2}{*}{ DnaJ (Hsp40) homolog, subfamily B, member 9 (DNAJB9) } & for & GGATGCTGAAGCAAAATTCA & $150 \mathrm{bp}$ \\
\hline & rev & AATGACTGCTCAAAAGAACTTCC & \\
\hline \multirow{2}{*}{ E2F transcription factor 2 (E2F2) } & for & CGCATCTATGACATCACCAAC & 157 bp \\
\hline & rev & TGTTCATCAGCTCCTTCAGC & \\
\hline \multirow[t]{2}{*}{ Estrogen receptor, alpha (ESRI) } & for & CAGACACTTTGATCCACCTGA & 179 bp \\
\hline & rev & CTCCAGCAGCAGGTCATAGA & \\
\hline \multirow{2}{*}{ GREBI protein (GREBI) } & for & ATCATCCTGAACGTGGACCT & $15 \mid \mathrm{bp}$ \\
\hline & rev & CCACGATCTGCTTCTTCATC & \\
\hline \multirow[t]{2}{*}{ Growth arrest and DNA-damage-inducible, alpha (GADD45A) } & for & GGAGGAAGTGCTCAGCAAA & $169 \mathrm{bp}$ \\
\hline & rev & CTGGATCAGGGTGAAGTGG & \\
\hline \multirow[t]{2}{*}{ Metastasis associated in lung adenocarcinoma transcript I (MALAT-I) } & for & TGCAATTTGGTGATGAAGGT & $161 \mathrm{bp}$ \\
\hline & rev & CAACATATTGCCGACCTCAC & \\
\hline \multirow[t]{2}{*}{ Proliferating cell nuclear antigen (PCNA) } & for & TTGCACTGAGGTACCTGAACTT & $160 \mathrm{bp}$ \\
\hline & rev & ССТTСТTCATCСТCGATCTTG & \\
\hline \multirow{2}{*}{ Vascular endothelial growth factor (VEGF) } & for & CATCTTCAAGCCATCCTGTG & 179 bp \\
\hline & rev & TGCATTCACATTTGTTGTGC & \\
\hline \multirow{2}{*}{ Glyceraldehyde-3-phosphate dehydrogenase (GAPDH) } & for & ACCAGGTGGTCTCCTCTGAC & $173 \mathrm{bp}$ \\
\hline & rev & TTACTCCTTGGAGGCCATGT & \\
\hline
\end{tabular}

described. Regulated (differentially expressed) genes were identified using the following selection criteria: minimal signal intensity $>$ median and fold change $v$ s. control $>1.5$ in two independent experiments. With these criteria we identified 544 probe sets ( $1 \%$ from the more than 54000 probe sets on the HG U133 Plus 2.0 Array) representing 431 genes regulated by the extract. The false positive rate with the criteria used is about $5 \%$ based on random permutation analysis of the gene expression results, showing a mean of 22 to 32 regulated probe sets $(22 / 544 \sim 4.0 \%$; $32 / 544 \sim 5.9 \%)$.

Of the genes regulated by the extract, 335 transcripts $(78 \%)$ were upregulated and 96 genes $(22 \%)$ were downregulated. These genes were grouped into functional categories according to Gene Ontology terms and gene description at the NetAff $\mathrm{x}^{\mathrm{TM}}$ Analysis Center [36] and addition literature search. Most of the regulated genes could be clearly assigned to 5 larger groups of functionally related genes (subgroups in brackets): apoptosis, proliferation (cell cycle, replication), general growth (RNA processing, protein turnover, transcription, cell structure and organization), signaling \& transport (signal transduction, transport) and metabolism (oxidoreductases, biosynthesis and catabolism). Genes that could not be assigned to any of these groups were summarized as others (Figure 3). Furthermore, because of a striking presence of many transcripts linked to cellular stress response, we also created the functional category stress response, which is not directly linked to the other categories. Genes functionally connected to this group are already members of one of the 6 main categories (Figure $3)$. In most groups more genes were stimulated than inhibited. In the group proliferation, in contrast, a majority of genes appeared to be downregulated. Genes for this category as well as the groups/subgroups apoptosis, protein turnover, oxidoreductases and stress response are all statistically overrepresented among the black cohosh regulated genes ( $\mathrm{p}<0.001$, two-sided $\mathrm{p}$-value Fisher Exact Test). For two groups - proliferation (cell cycle, DNA replication) and stress response - the overrepresentation is very highly significant.

Regulation of 13 genes representing the 6 functional categories, apoptosis, proliferation, general growth, signaling \& transport, metabolism and others, were verified by real-time RT-PCR from independent samples to confirm the regulation of genes connected to the major cellular effects observed. 


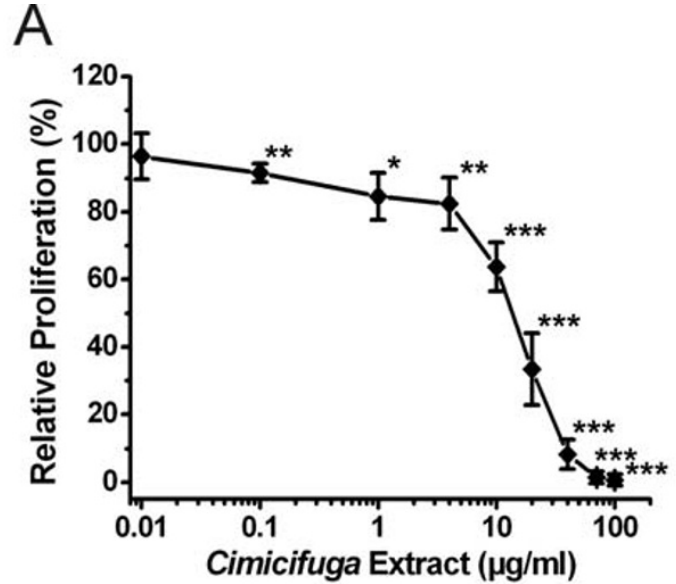

B
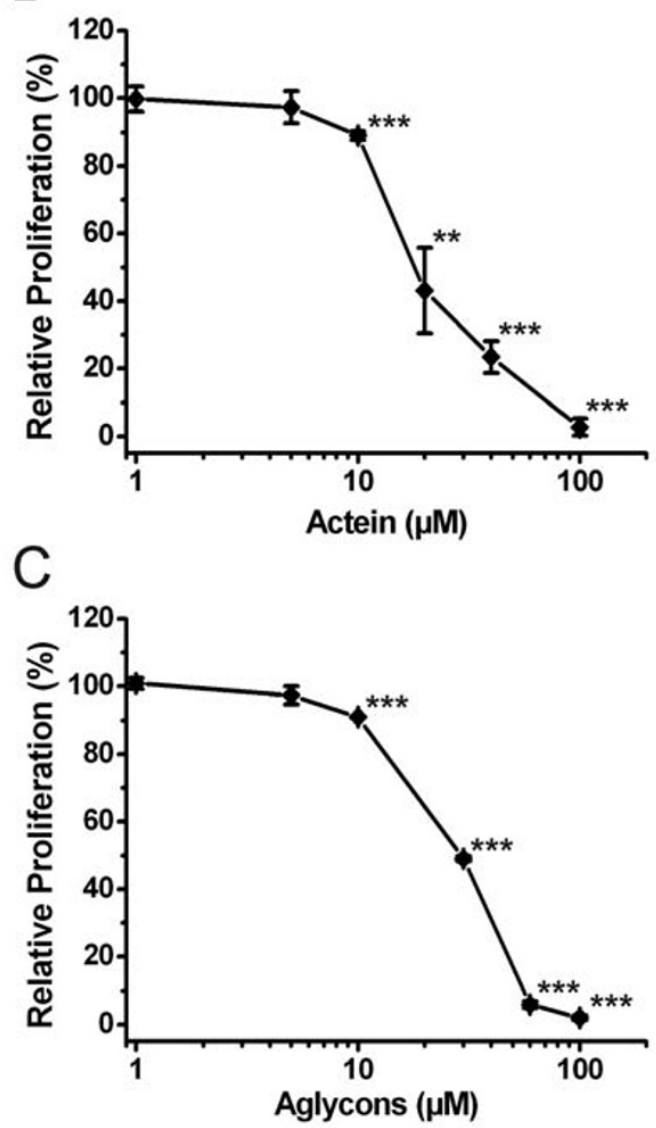

Figure 2

Proliferation assay: Effects on growth rate of MCF-7 cells. MCF-7 cells were treated with (A) dichloromethane extract of black cohosh rhizome, (B) actein or (C) mixture of aglycons derived from cycloartane glycosides. Controls (I00\% proliferation) contained $0.1 \%$ DMSO. After $120 \mathrm{~h}$ cell number was determined by MTT dye-reduction assay. Relative proliferation data are presented as means \pm SD $(n=3-$ 6). ${ }^{*} p<0.05$, **p $<0.01$, *** $p<0.00$ I vs. control (Student's ttest).
The cellular effects of the functional groups regulated by black cohosh are summarized in Figure 4. Expression values of selected genes are presented in Table 2. A complete list of all regulated genes is available [see Additional file $1]$. The data discussed in this publication have also been deposited in NCBIs Gene Expression Omnibus (GEO) [37], and are accessible through GEO Series accession number GSE6800.

\section{Proliferation}

In agreement with the anti-proliferative effect of the black cohosh extract, genes involved in proliferation control were significantly overrepresented. Transcripts related to cell cycle regulation and DNA replication were regulated in a manner supporting cell cycle arrest. Genes, whose products are involved in the transition from G1 to S-phase appeared to be downregulated, such as cyclins (CCNA2, CCNE2, CCNF), cyclin-dependent kinase 2 (CDK2) and transcription regulators (E2F2, PCNA, SKP2), whereas transcription of inhibitory genes cyclin G2 (CCNG2), GADD45A (growth arrest and DNA-damage-inducible, alpha) and $p 21^{\text {cip } 1}$ (cyclin-dependent kinase inhibitor 1A, CDKN1A) was increased. Elevated levels of CCNG2, cyclin B1 interacting protein 1 (CCNB1IP1), forkhead box O3A (FOXO3A), GADD45A and $p 21^{c i p 1}$ genes as well as downregulation of cyclin A2 (CCNA2) and CDK2 provided evidence that cell cycle progression might be additionally arrested at the G2/M-checkpoint. The level of various DNA replication related genes (CDC6, CDT1, FEN1, MCM2, MCM3, MCM4, MCM5, MCM7, MCM10, Pfs2, $R F C 3$ ) was also reduced, thereby suggesting a reduction in the replication rate. All cell cycle related effects are summarized in Figure 5, which shows a cell cycle diagram from GenMAPP (Gene Map Annotator and Pathway Profiler, Gladstone Institutes, University of San Francisco, San Francisco, CA) [38], in which up- and downregulated genes are marked.

\section{Apoptosis}

In addition to the regulation of genes involved in proliferation control, we also observed regulation of apoptosislinked genes in a pro-apoptotic manner, indicating that the extract could sensitize breast cancer cells for apoptotic events. An increase in apoptotic events would also contribute to the decrease in cellular proliferation observed. In cells treated with black cohosh the transcript of the apoptosis inhibitor survivin (baculoviral IAP repeat-containing 5, BIRC5) was downregulated, whereas genes coding for apoptosis-inducing and -supporting products (BNIP3L, TNFRSF10B, TP53INP1) were increased. FOXO3A, GADD45A, GDF 15 (growth differentiation factor $15)$ and $p 21^{c i p 1}$, whose mRNA levels increased, are also connected with apoptosis in addition to their role in cell cycle control. Transcript of tyrosyl-tRNA synthetase (YARS), whose secretion is linked to apoptotic events 


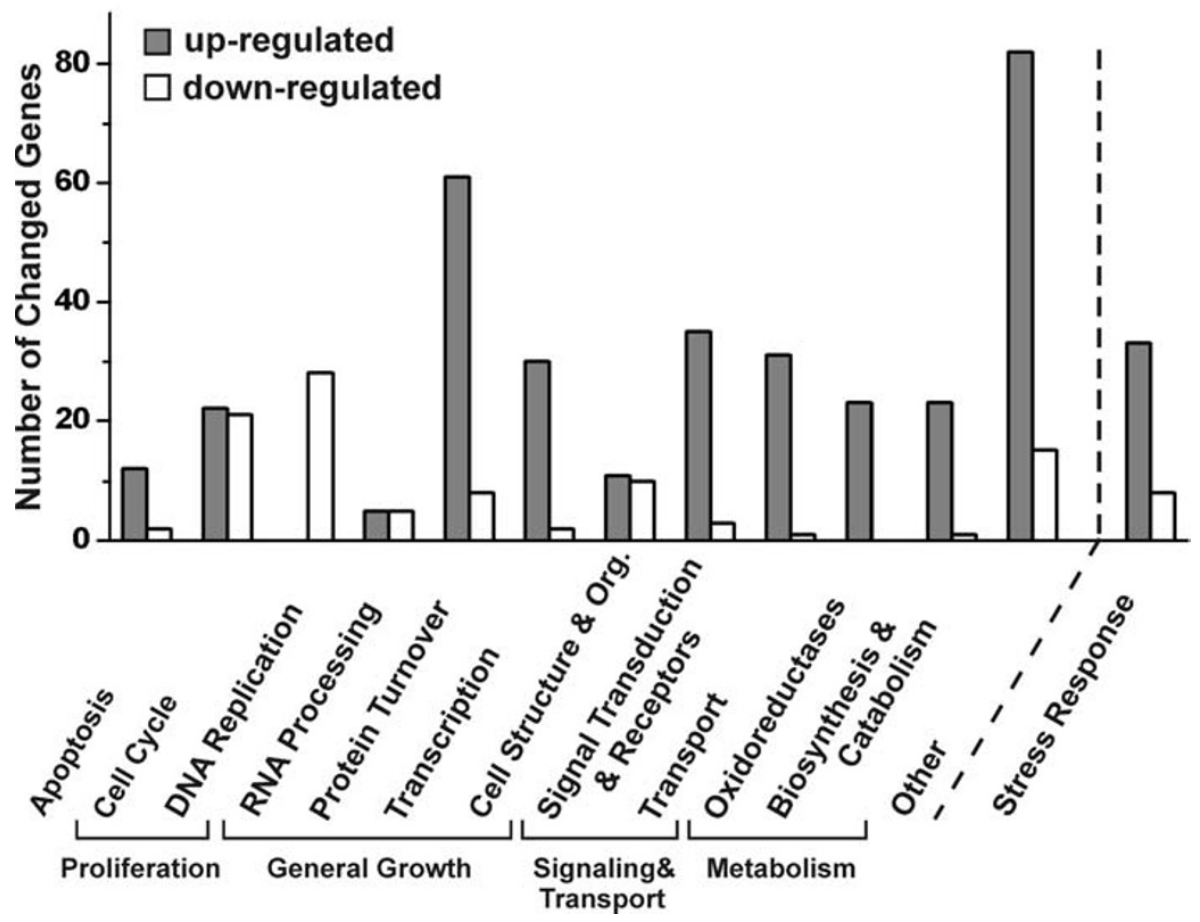

Figure 3

Functional categories of genes regulated in MCF-7 cells after $24 \mathrm{~h}$ incubation with black cohosh extract. Genes were grouped in 5 large groups (Apoptosis, Proliferation, General Growth, Signaling \& Transport, Metabolism), some consisting of subgroups.

Genes that are not clearly associated with these groups are summarized in the category others. The category stress response contains genes also grouped into one of the 6 main classes. Each bar represents the number of genes that were up- (dark) or downregulated (white) in the respective group.

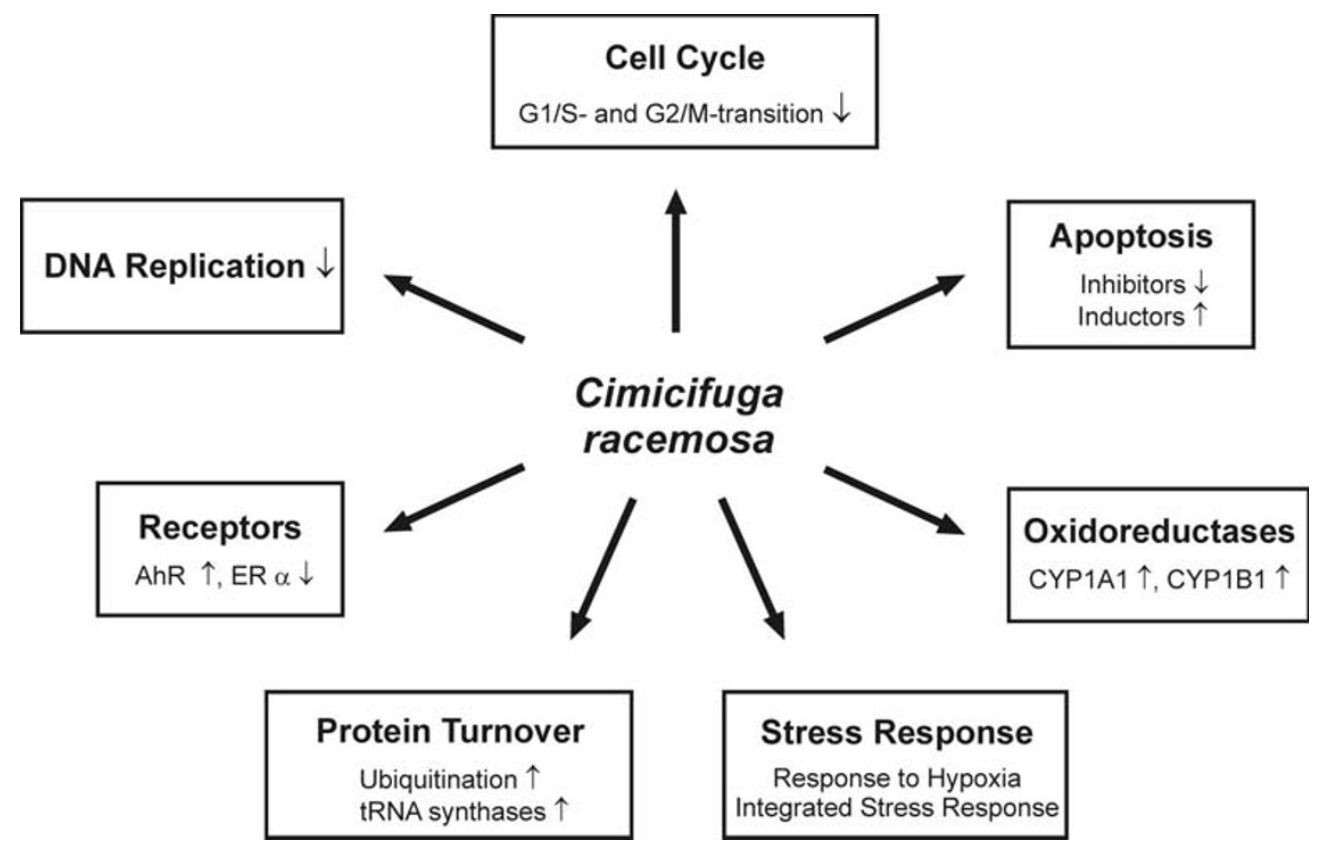

Figure 4

Summary of effects of black cohosh in MCF-7 cells at mRNA level observed with the microarray experiment. $\downarrow$ represents inhibition, $\uparrow$ represents stimulation. 
Table 2: List of selected genes regulated by black cohosh extract in MCF-7 cells. Genes are listed with symbol, GenBank accession number and fold changes vs. DMSO control of two independent microarray experiments. Genes in bold are associated to stress response. Those written in italics have been verified by real-time RT-PCR. A full list with all 43 I genes is available [see Additional file I].

\begin{tabular}{|c|c|c|c|}
\hline \multirow[t]{2}{*}{ Gene Title } & \multirow[t]{2}{*}{$\begin{array}{l}\text { Gene } \\
\text { Symbol }\end{array}$} & \multirow[t]{2}{*}{$\begin{array}{l}\text { Accession } \\
\text { No. }\end{array}$} & $\begin{array}{c}\text { Fold } \\
\text { Change }\end{array}$ \\
\hline & & & \#I \\
\hline
\end{tabular}

\author{
APOPTOSIS \\ DNA-damage-inducible transcript 4 \\ P8 protein (candidate of metastasis I) \\ Tumor protein $\mathrm{p} 53$ inducible nuclear protein I \\ Tumor necrosis factor receptor superfamily, member $10 \mathrm{~b}$ \\ Immediate early response 3 \\ BCL2/adenovirus EIB 19 kda interacting protein 3-like \\ Helicase, lymphoid-specific \\ Baculoviral IAP repeat-containing 5 (survivin)
}

\section{PROLIFERATION}

Cell cycle/Proliferation

Growth differentiation factor 15

Vascular endothelial growth factor

Cyclin G2

DNA-damage-inducible transcript 3 (CHOP-I0, GADD I 53)

RAS, dexamethasone-induced I

Sestrin 2

Growth arrest and DNA-damage-inducible, alpha

Cyclin-dependent kinase inhibitor IA (p2 I, Cip I)

Forkhead box O3A

Cyclin $\mathrm{BI}$ interacting protein I

Cyclin-dependent kinase 7

Cyclin F

S-phase kinase-associated protein 2 (p45)

Chromatin assembly factor I, subunit A (p I 50)

Membrane-associated tyrosine- and threonine-specific cdc2-inhibitory kinase

E2F transcription factor 2

Kinetochore protein Spc24

Cyclin A2

Proliferation-related $\mathrm{Ki}-67$ antigen

Cyclin E2

E2F transcription factor 7

Kinesin family member II (Eg5)

DNA replication, repair and synthesis

Recq protein-like 4

Cyclin-dependent kinase 2

Minichromosome maintenance deficient 3 (S. Cerevisiae)

CDC6 cell division cycle 6 homolog (S. Cerevisiae)

DNA replication factor

BRCAI interacting protein C-terminal helicase I

Minichromosome maintenance deficient 5, cell division cycle 46 (S. Cerevisiae)

Minichromosome maintenance deficient 7 (S. Cerevisiae)

Ubiquitin-like, containing PHD and RING finger domains, I

Thymidine kinase I, soluble

Proliferating cell nuclear antigen

Replication factor C (activator I) 3, 38 kda

Minichromosome maintenance deficient 2, mitotin (S. Cerevisiae)

DNA replication complex GINS protein PSF2

Flap structure-specific endonuclease I

Minichromosome maintenance deficient 4 (S. Cerevisiae)

Thymidylate synthetase

$\begin{array}{llll}\text { DDIT4 } & \text { NM 019058 } & 5.1 & 5.6 \\ \text { P8 } & \underline{A F I 35266} & 4.4 & 2.7 \\ \text { TP53INPI } & \text { AW341649 } & 3.5 & 3.1 \\ \text { TNFRSFIOB } & \underline{A F 016266} & 2.5 & 2.7 \\ \text { IER3 } & \underline{\text { NM } 003897} & 2.0 & 1.9 \\ \text { BNIP3L } & \underline{A L I 32665} & 1.8 & 1.6 \\ \text { HELLS } & \underline{A \mid 650364} & -2.8 & -2.7 \\ \text { BIRC5 } & \underline{A A 648913} & -3.1 & -2.0\end{array}$

\begin{tabular}{|c|c|c|c|}
\hline GDFI5 & AF003934 & 6.0 & 4.5 \\
\hline VEGF & AF022375 & 4.6 & 4.2 \\
\hline CCNG2 & AWI34535 & 2.8 & 2.3 \\
\hline DDIT3 & $\mathrm{BC} 003637$ & 2.6 & 2.7 \\
\hline RASDI & AF069506 & 2.6 & 2.4 \\
\hline SESN2 & $\mathrm{BF}|3| 886$ & 2.4 & 2.8 \\
\hline GADD45A & NM 001924 & 2.2 & 2.6 \\
\hline CDKNIA & NM 000389 & 1.8 & 1.6 \\
\hline FOXO3A & AV725666 & 1.8 & 1.9 \\
\hline CCNBIIPI & NM 021178 & 1.6 & 1.6 \\
\hline CDK7 & $\underline{\mathrm{L} 20320}$ & 1.6 & 1.6 \\
\hline CCNF & $\underline{U 17105}$ & -1.5 & -1.9 \\
\hline SKP2 & $\mathrm{BC} 001441$ & -1.6 & -1.6 \\
\hline CHAFIA & BF062223 & -1.7 & -1.6 \\
\hline PKMYTI & NM 004203 & -1.8 & -1.6 \\
\hline$E 2 F 2$ & AL561296 & -2.2 & -1.6 \\
\hline Spc24 & Al469788 & -2.2 & -1.8 \\
\hline CCNA2 & NM 001237 & -2.3 & -1.5 \\
\hline MKI67 & AU152107 & -2.3 & -1.9 \\
\hline CCNE2 & AFII 2857 & -2.6 & -3.0 \\
\hline E2F7 & $\mathrm{A} 1341146$ & -2.7 & -2.1 \\
\hline KIFII & NM 004523 & -2.7 & -1.7 \\
\hline RECQL4 & NM 004260 & -1.7 & -1.7 \\
\hline CDK2 & ABO12305 & -2.1 & -1.5 \\
\hline MCM3 & NM 002388 & -2.1 & -1.8 \\
\hline CDC6 & NM 001254 & -2.5 & -1.6 \\
\hline CDTI & AF321125 & -2.5 & -1.7 \\
\hline BRIPI & AF360549 & -2.6 & -1.7 \\
\hline MCM5 & AA807529 & -2.6 & -1.7 \\
\hline MCM7 & AF279900 & -2.7 & -1.8 \\
\hline UHRFI & AK025578 & -2.7 & -2.7 \\
\hline TKI & $\underline{\mathrm{BC} 007986}$ & -2.8 & -1.7 \\
\hline PCNA & NM 002592 & -2.9 & -1.9 \\
\hline RFC3 & NM 002915 & -3.0 & -1.7 \\
\hline MCM2 & NM 004526 & -3.1 & -1.6 \\
\hline Pfs2 & $\mathrm{BC} 003186$ & -3.3 & -1.5 \\
\hline FEN I & NM 0041II & -3.4 & -2.5 \\
\hline MCM4 & Al859865 & -3.4 & -2.4 \\
\hline TYMS & AB077208 & -3.4 & -2.4 \\
\hline
\end{tabular}


Table 2: List of selected genes regulated by black cohosh extract in MCF-7 cells. Genes are listed with symbol, GenBank accession number and fold changes vs. DMSO control of two independent microarray experiments. Genes in bold are associated to stress response. Those written in italics have been verified by real-time RT-PCR. A full list with all 43 I genes is available [see Additional file I]. (Continued)

\section{GENERAL GROWTH}

\section{Protein processing}

Chromosome I open reading frame 24

Seryl-tRNA synthetase

DnaJ (Hsp40) homolog, subfamily C, member 10

DnaJ (Hsp40) homolog, subfamily B, member 9

Homocysteine-inducible, endoplasmic reticulum stress-inducible, ubiquitin-like domain member I

Tryptophanyl-tRNA synthetase

MAP kinase-interacting serine/threonine kinase 2

Eukaryotic translation initiation factor $4 \mathrm{E}$ binding protein I

Stress 70 protein chaperone, microsome-associated, $60 \mathrm{kda}$

Eukaryotic translation initiation factor 2-alpha kinase 3 (syn. PERK)

Methionine-tRNA synthetase

Microtubule-associated protein I light chain 3 beta

Tyrosyl-tRNA synthetase

Cysteinyl-tRNA synthetase

Isoleucine-tRNA synthetase

F-box only protein II

Ubiquitin protein ligase E3 component n-recognin I

Glutamyl-prolyl-tRNA synthetase

Heat shock $70 \mathrm{kda}$ protein 5 (glucose-regulated protein, $78 \mathrm{kda}$ )

Transducin (beta)-like IX-linked

Ubiquitin specific protease 3

Eucaryotic translation initiation factor I

Glycyl-tRNA synthetase

SUMOI/sentrin specific protease 6

APG 12 autophagy I2-like (S. Cerevisiae)

Ubiquitin-fold modifier I

Heat shock $70 \mathrm{kda}$ protein 2

F-box only protein 5 (early mitotic inhibitor I)

Ubiquitin-conjugating enzyme E2C

Transcription

Basic helix-loop-helix domain containing, class B, 2

Trinucleotide repeat containing 9

Cbp/p300-interacting transactivator, with Glu/Asp-rich carboxy-terminal domain, 2

CCAAT/enhancer binding protein (C/EBP), beta

CCAAT/enhancer binding protein (C/EBP), gamma

Junction-mediating and regulatory protein

Endothelial PAS domain protein I (Hypoxia-inducible factor 2, alpha)

Nuclear factor (erythroid-derived 2)-like 2

Activating transcription factor 3

Activating transcription factor 4

Early growth response I

Nuclear factor (erythroid-derived 2)-like I

Chromobox homolog 4 (Pc class homolog, Drosophila)

Kruppel-like factor 4 (gut)

Zinc finger protein 36, C3H type-like 2

Cell organization, adhesion \& structure and cytoskeleton

Decay accelerating factor for complement (CD55, Cromer blood group system)

Ras homolog gene family, member B

\begin{tabular}{|c|c|c|c|}
\hline Clorf24 & AF288391 & 4.9 & 5.1 \\
\hline SARS & AU147785 & 4.4 & 4.0 \\
\hline DNAJCIO & BG168666 & 3.1 & 1.9 \\
\hline DNAJB9 & AL08008I & 2.9 & 2.3 \\
\hline HERPUD I & AF217990 & 2.5 & 2.0 \\
\hline WARS & NM 004184 & 2.5 & 2.2 \\
\hline MKNK2 & NM 017572 & 2.4 & 2.0 \\
\hline EIF4EBPI & AB044548 & 2.3 & 1.8 \\
\hline STCH & NM 006948 & 2.3 & 2.7 \\
\hline EIF2AK3 & NM 004836 & 2.2 & 1.7 \\
\hline MARS & AA621558 & 2.2 & 2.2 \\
\hline MAPILC3B & $\underline{A F 183417}$ & 2.2 & 1.9 \\
\hline YARS & AW245400 & 2.0 & 1.7 \\
\hline CARS & Al769685 & 1.9 & 2.0 \\
\hline IARS & NM 013417 & 1.9 & 2.0 \\
\hline FBXOII & $\underline{A L I 17620}$ & 1.9 & 1.7 \\
\hline UBRI & $\overline{A V 715153}$ & 1.9 & 1.8 \\
\hline EPRS & NM 004446 & 1.8 & 1.7 \\
\hline HSPA5 & AF216292 & 1.8 & 1.6 \\
\hline TBLIX & AW968555 & 1.8 & 1.9 \\
\hline USP3 & AF077040 & 1.8 & 1.8 \\
\hline EIF I & AF08344I & 1.7 & 1.7 \\
\hline GARS & D30658 & 1.7 & 2.3 \\
\hline SENP6 & $\mathrm{AF} 306508$ & 1.7 & 1.6 \\
\hline APG I $2 L$ & $\overline{\text { BE965998 }}$ & 1.6 & 1.7 \\
\hline Ufm I & NM 016617 & 1.6 & 1.6 \\
\hline HSPA2 & $\underline{\mathrm{U} 56725}$ & -1.7 & -1.9 \\
\hline FBXO5 & AK026197 & -2.0 & -1.7 \\
\hline UBE2C & $\overline{N M \quad 007019}$ & -2.0 & -1.6 \\
\hline BHLHB2 & NM 003670 & 3.6 & 2.6 \\
\hline TNRC9 & AK025084 & 3.4 & 2.1 \\
\hline CITED2 & AFI09161 & 3.1 & 1.5 \\
\hline CEBPB & AL564683 & 2.4 & 2.3 \\
\hline CEBPG & NM 001806 & 2.2 & 2.4 \\
\hline JMY & BF447037 & 2.2 & 1.6 \\
\hline EPASI & AF052094 & 2.1 & 1.9 \\
\hline NFE2L2 & NM 006164 & 2.0 & 1.5 \\
\hline ATF3 & NM 001674 & 1.8 & 2.0 \\
\hline ATF4 & NM 001675 & 1.7 & 1.5 \\
\hline EGRI & Al459194 & 1.7 & 4.7 \\
\hline NFE2LI & NM 003204 & 1.6 & 1.6 \\
\hline $\mathrm{CB} \times 4$ & Al570531 & 1.5 & 1.8 \\
\hline KLF4 & $\overline{\text { BF5 I 4079 }}$ & 1.5 & 1.8 \\
\hline ZFP36L2 & $\mathrm{Al} 356398$ & -3.1 & -2.1 \\
\hline DAF & NM 000574 & 3.6 & 3.3 \\
\hline RHOB & Al263909 & -1.8 & -1.6 \\
\hline
\end{tabular}


Table 2: List of selected genes regulated by black cohosh extract in MCF-7 cells. Genes are listed with symbol, GenBank accession number and fold changes vs. DMSO control of two independent microarray experiments. Genes in bold are associated to stress response. Those written in italics have been verified by real-time RT-PCR. A full list with all 43 I genes is available [see Additional file I]. (Continued)

\begin{tabular}{|c|c|c|c|c|}
\hline Unc-5 homolog B (C. Elegans) & UNC5B & AK022859 & 3.3 & 2.1 \\
\hline Stanniocalcin 2 & STC2 & $\mathrm{BC} 000658$ & 2.6 & 2.3 \\
\hline TRAF family member-associated NFKB activator & TANK & $\underline{\text { U59863 }}$ & 2.2 & 2.3 \\
\hline Interferon gamma receptor I & IFNGR I & NM 000416 & 2.1 & 1.6 \\
\hline Mitogen-inducible gene 6 & MIG-6 & AL0344I7 & 2.1 & 2.5 \\
\hline Ras association (ralgds/AF-6) domain family 3 & RASSF3 & Al628605 & 2.0 & 1.5 \\
\hline Aryl hydrocarbon receptor & AHR & NM 001621 & 1.8 & 1.8 \\
\hline Tribbles homolog I (Drosophila & TRIBI & NM 025195 & 1.7 & 1.6 \\
\hline Tribbles homolog 3 (Drosophila) & TRIB3 & NM 021158 & 1.7 & 1.6 \\
\hline Aryl hydrocarbon receptor nuclear translocator-like & ARNTL & $\mathrm{AB} 000815$ & 1.6 & 1.8 \\
\hline Casein kinase I, gamma 3 & CSNKIG3 & NM 004384 & 1.5 & 1.6 \\
\hline Hypoxia-inducible factor I, alpha subunit & HIFIA & NM 001530 & 1.5 & 1.5 \\
\hline c-Jun N-terminal kinase I (mitogen-activated protein kinase 8, MAPK8) & JNKI & AUI52505 & 1.5 & 1.5 \\
\hline Tyrosine 3-monooxygenase/tryptophan 5-monooxygenase activation protein, eta polypeptide & YWHAH & NM 003405 & -1.8 & -1.9 \\
\hline Estrogen receptor, alpha & ESRI & NM 000125 & -2.0 & -1.8 \\
\hline \multicolumn{5}{|l|}{ Transport } \\
\hline Solute carrier family 7, (cationic amino acid transporter, $y+$ system) member II & SLC7AII & AA488687 & 6.2 & 5.7 \\
\hline Potassium voltage-gated channel, Isk-related family, member 4 & KCNE4 & $\underline{\mathrm{A} 1002715}$ & 3.1 & 2.1 \\
\hline Solute carrier family 7 (cationic amino acid transporter, $y+$ system), member 5 & SLC7A5 & $\overline{\mathrm{AB} 018009}$ & 2.3 & 2.0 \\
\hline Solute carrier family 38, member 2 & SLC38A2 & NM 018976 & 2.0 & 2.0 \\
\hline Ferritin $\mathrm{H}$ & FTHI & $\underline{\mathrm{AA} 083483}$ & 1.9 & 1.9 \\
\hline Solute carrier family I (glutamate/neutral amino acid transporter), member 4 & SLCIA4 & $\underline{A l 889380}$ & 1.6 & 1.6 \\
\hline \multicolumn{5}{|l|}{ METABOLISM } \\
\hline \multicolumn{5}{|l|}{ Oxidoreductase activity } \\
\hline Cytochrome P450, family I, subfamily A, polypeptide I & CYPIAI & NM 000499 & 12.4 & 3.5 \\
\hline Aldo-keto reductase family I, member CI (20-alpha (3-alpha)-hydroxysteroid dehydrogenase) & AKRICI & M33376 & 5.5 & 2.3 \\
\hline Aldehyde dehydrogenase I family, member L2 & ALDHIL2 & Al654224 & 5.0 & 2.2 \\
\hline Cytochrome P450, family I, subfamily B, polypeptide I & CYPIBI & NM 000104 & 4.1 & 2.7 \\
\hline Heme oxygenase (decycling) I & HMOXI & NM 002133 & 3.3 & 2.1 \\
\hline Glutaredoxin (thioltransferase) & GLRX & AFI62769 & 3.0 & 1.9 \\
\hline Sterol-C4-methyl oxidase-like & SC4MOL & AV704962 & 2.5 & 2.4 \\
\hline Aspartate beta-hydroxylase & ASPH & AF289489 & 2.4 & 2.2 \\
\hline 5-Methyltetrahydrofolate-homocysteine methyltransferase reductase & MTRR & NM 024010 & 2.3 & 2.2 \\
\hline Methylene tetrahydrofolate dehydrogenase (NAD+ dependent) & MTHFD2 & NM 006636 & 1.9 & 2.0 \\
\hline Sterol-C5-desaturase & SC5DL & D85181 & 1.5 & 1.6 \\
\hline Cytochrome P450, family 5I, subfamily A, polypeptide I (Sterol I4-alpha-demethylase) & CYP5IAI & NM 000786 & 1.6 & 1.6 \\
\hline Farnesyl-diphosphate farnesyltransferase I (Squalene synthase) & FDFTI & AA872727 & 1.6 & 1.7 \\
\hline 3-Hydroxy-3-methylglutaryl-Coenzyme A reductase & HMGCR & $\overline{\mathrm{AL} 518627}$ & 1.8 & 1.7 \\
\hline \multicolumn{5}{|l|}{ Biosynthesis/Catabolism } \\
\hline Asparagine synthetase & ASNS & NM 001673 & 3.7 & 4.1 \\
\hline Acyl-coa synthetase long-chain family member I & ACSLI & NM 021122 & 2.6 & 2.2 \\
\hline Phosphoenolpyruvate carboxykinase 2 (mitochondrial) & PCK2 & NM 004563 & 2.5 & 3.3 \\
\hline Spermidine/spermine NI-acetyltransferase & SAT & BE326919 & 1.6 & 1.8 \\
\hline \multicolumn{5}{|l|}{ OTHERS } \\
\hline Metastasis associated in lung adenocarcinoma transcript I & MALAT-I & BG534952 & 11.0 & 3.1 \\
\hline SIO0 calcium binding protein P & SIOOP & NM 005980 & 5.8 & 5.1 \\
\hline Gastric-associated differentially-expressed protein YA6IP, drug sensitive protein I & --- & $\underline{A F 220415}$ & 5.6 & 2.1 \\
\hline Hypothetical protein LOC22217I & LOC22217I & Al347918 & 5.1 & 3.6 \\
\hline Brain expressed $X$-linked 2 & BEX2 & $\overline{\mathrm{AF} 251053}$ & 4.6 & 3.6 \\
\hline Myozenin 2 (calcisarcin I) & MYOZ2 & Al475544 & 4.5 & 3.8 \\
\hline WD40 repeat protein Interacting with phosphoinositides of $49 \mathrm{kda}$ & WIPI49 & AW052084 & 3.5 & 2.1 \\
\hline SLIT and NTRK-like family, member 6 & SLITRK6 & Al680986 & 3.4 & 2.4 \\
\hline
\end{tabular}




\section{Cell cycle}

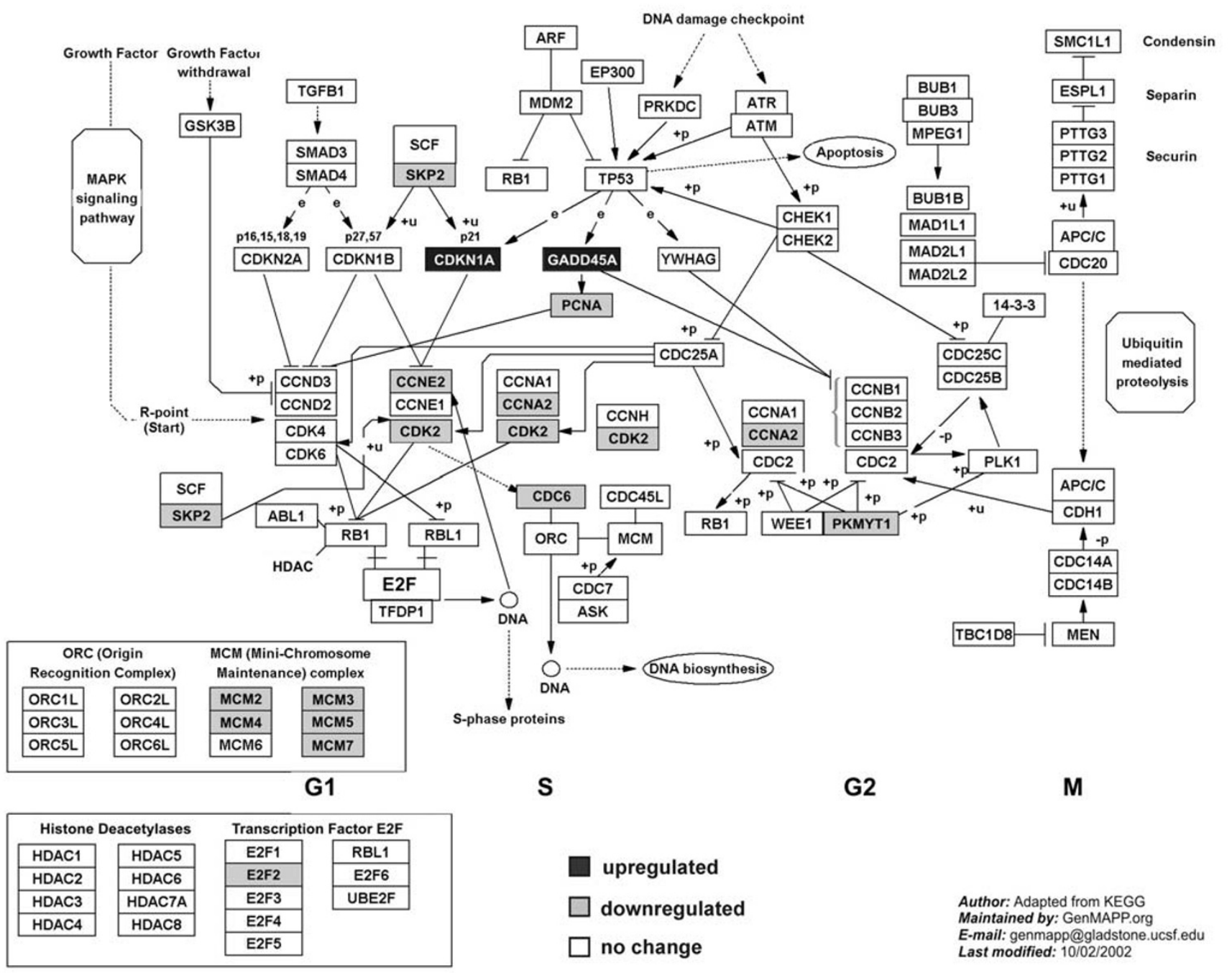

Figure 5

Cell cycle pathway diagram obtained from GenMAPP (Gene Map Annotator and Pathway Profiler, Gladstone Institutes, University of San Francisco, San Francisco, CA [38]. Proteins involved in cell cycle control are displayed from left to right as cell cycle progresses from GI through S and G2 to M-phase. Genes with boxes marked black were upregulated. Genes marked with grey boxes were downregulated.

[39], was upregulated. Downregulation of lymphoid-specific helicase (HELLS), as observed in our experiments, has been reported to be associated with apoptosis [40]. The upregulation of $c$-Jun $N$-terminal kinase $1(J N K 1=$ MAPK8) and DNA-damage-inducible transcript 3 (DDIT3 $=$ CHOP $=$ GADD153), as observed in our experiments, have been reported as related to stress-induced apoptosis $[41,42]$. $p 8$ Protein (p8), immediate early response 3 (IER3) and DNAdamage inducible transcript 4 (DDIT4, also known as REDD1 or RTP801), whose transcript was strongly upregulated, are known to be expressed under cellular stress (described later) and have been associated with both proand anti-apoptotic events [43-46].

\section{Stress response}

In relation to the results above, overexpression of transcripts involved with response to cellular stress was highly statistically significant after treatment with black cohosh extract. Among different functional categories we identified some 40 transcripts associated with metabolic stress response such as hypoxia [47], mal- or unfolded protein response in the endoplasmic reticulum $[48,49]$ or starvation for amino acids or glucose [50,51] (Figure 6). Tran- 


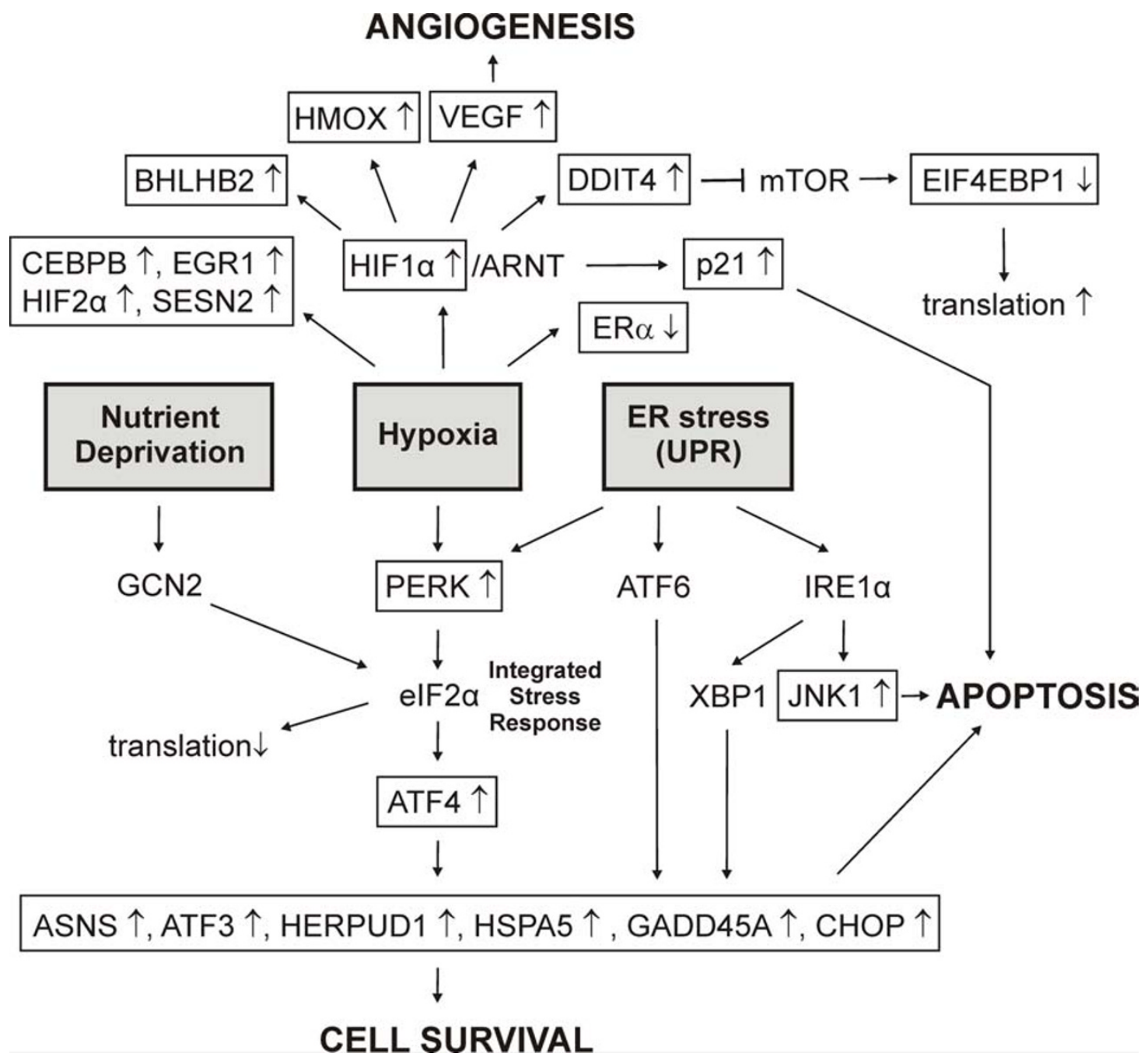

Figure 6

Stress response pathways affected by black cohosh at the transcriptional level. Genes marked by boxes were regulated in MCF-7 cells after treatment with black cohosh extract. $\uparrow$ represents up-regulation, $\downarrow$ represents down-regulation. (Abbreviations: ATF6, activating transcription factor 6; XBPI, $x$ box binding protein I; IREI $\alpha$, Serine/threonine-protein kinase/endoribonuclease, Inositol-requiring I).

script of hypoxia inducible factor $1 \alpha$ (HIF1 $\alpha$; HIF1A), a key regulator in hypoxia, was upregulated. A heterodimer of HIF1 $\alpha /$ ARNT (HIF1) binds to hypoxia-responsive elements (HREs), thereby regulating the expression of hypoxia-response genes. Vascular endothelial growth factor (VEGF), heme oxygenase 1 (HMOX1), basic helix-loop-helix domain containing, class B, 2 (BHLHB2),p21 cip 1 and DDIT4 - these transcripts were also upregulated - are known to be direct target genes $[47,52,53]$. A hypoxia response pathway via mTOR (mammalian target of rapamycin) including inactivation of EIF4EBP1 (Eukaryotic translation initiation factor $4 \mathrm{E}$ binding protein 1) and finally resulting in increased mRNA translation is known to be inhibited by DDIT4 [52]. This could explain the increase of EIF4EBP1 mRNA we observed in our experiment. The increases of CCAAT/enhancer binding protein, beta (CEBPB), endothelial PAS domain protein 1 $(E P A S 1=H I F 2 \alpha)$, early growth response 1 (EGR1) and sestrin 2 (SESN2) mRNA are also related to hypoxia $[53,54]$.

Furthermore, we observed regulation of genes related to endoplasmic reticulum stress response (unfolded protein response, UPR), which involves the activation of three different pathways. Transcription of c-Jun N-terminal kinase 1 (JNK1 = MAPK8) was upregulated in our experiment. JNK1 is a target of one UPR-pathway and its activation may lead to apoptosis [42,55]. Phosphorylation of eukaryotic translation initiation factor $2 \alpha(\mathrm{eIF} 2 \alpha)$ at 
Ser51 is involved not only in UPR but also in responses to hypoxia, nutrient deprivation and other cellular stresses. Hence, this evolutionarily conserved pathway has been termed the integrated stress response (ISR) $[41,52]$. PERK (EIF2AK3, eukaryotic translation initiation factor 2-alpha kinase 3), whose mRNA-level was increased by black cohosh treatment, is a kinase linking hypoxia stress reponse and UPR to eIF2 $\alpha$-phosphorylation, whereas amino acid and glucose starvation response acts via GCN2 kinase. As a consequence of eIF2 $\alpha$-phosphorylation the translation of most mRNAs is inhibited, but paradoxically the translation of activating transcription factor 4 (ATF4) is increased. We observed an upregulation of the ATF4 gene as well as various ATF4-induced downstream target genes, e.g. ASNS (asparagine synthetase), ATF3 (activating transcription factor 3), CHOP, GADD45A, HERPUD1 (homocysteine-inducible, endoplasmic reticulum stress-inducible, ubiquitin-like domain member 1), HSPA5 (heat shock $70 \mathrm{kDa}$ protein 5). Gene products of these transcripts are involved in cell survival and tumorigenesis as well as apoptotic events $[42,49,56]$.

\section{Protein turnover}

In the context of mis- or unfolded protein response some other processes of protein turnover are affected by black cohosh extract. The expression levels of various ubiquitin cycle-related genes (FBOX5, FBOX11, MAP1LC3B, SENP6, TBL1X, UBE2C, UBR1, Ufm1, USP3) were influenced by black cohosh. Some of these transcripts code for products involved with cell cycle progression and were regulated in a cell cycle arresting manner, emphasizing our results described above. Inhibitory CCNB1IP1 was upregulated, whereas SKP2 (S-phase kinase-associated protein 2; p45) and UHRF1 (Ubiquitin-like, containing PHD and RING finger domains, 1) were downregulated. Furthermore, mRNAlevels of eight different aminoacyl-tRNA synthetases (CARS, EPRS, GARS, IARS, MARS, SARS, WARS, YARS) were upregulated.

\section{Oxidoreductases}

In response to black cohosh treatment, transcripts of several oxidoreductases involved with metabolism of xenobiotics were affected. In some cases we observed strong induction. The most prominent upregulation of all Cimcifuga regulated genes occurred for CYP1A1 (cytochrome P450, family 1, subfamily A, polypeptide 1). In the microarray experiments the increase was 12.4 and 3.5 fold, while RT-PCR gave even higher changes $(28.5 \pm 14.0$ fold, $\mathrm{p}<$ 0.01 and $19.2 \pm 10.9$ fold, $\mathrm{p}<0.05)$. This was accompanied by a marked but lower increase of CYP1B1 (cytochrome P450, family 1, subfamily B, polypeptide 1). Both enzymes are known to be activated by xenobiotics through the aryl hydrocarbon receptor pathway. Transcript of heme oxygenase 1 (HMOX1), an essential enzyme in heme catabolism and a direct target of HIF1 (see stress response), was also upregulated. Finally, transcripts of several enzymes of the cholesterol biosynthesis pathway (CYP51A1, FDFT1, HMGCR, SC4MOL, SC5DL) were marginally increased.

\section{Receptors}

Interestingly, transcription of the aryl hydrocarbon receptor (AhR) which regulates expression of the CYPs, was also increased. Furthermore, we observed a downregulation of the estrogen receptor $\alpha$ gene (ESR1). This regulation has already been reported in response to hypoxic stress [57]. mRNAs coding for interferon gamma receptor 1 (IFNGR1) appeared to be upregulated. The latter promotes effects of interferon $\gamma$, whose antitumor activity has previously been reported [58].

\section{Others}

Within this category, two tumor-associated transcripts showed largest upregulation. MALAT-1 (metastasis in lung adenocarcinoma transcript 1 ), a recently identified noncoding RNA, has been shown to be activated in early-stage lung cancer. High-level expression is associated to low survival rates of patients due to high risk to develop metastatis [59]. S100P (S100 calcium binding protein P) was reported as marker of breast cancer initiation. Expression of S100P as well as FTH1 (Ferritin H), an iron-binding protein, whose transcript was also upregulated by black cohosh, is associated to immortalization and transformation of breast epithelial cells [60].

\section{Comparison of the expression pattern of black cohosh with tamoxifen and E2}

Expression profiles with $17 \beta$-estradiol and the estrogen receptor-antagonist tamoxifen were investigated in parallel to compare the patterns with the black cohosh extract. After treatment with $1 \mathrm{nM}$ E2 146 transcripts met our selection criteria, among these known estrogen-regulated genes such as insulin-like growth factor binding protein 4 (IGFBP4) or GREB1 protein (GREB1). The latter transcript was strongly upregulated (microarray: 21.7 and 10.4 fold; RT-PCR: $26.6 \pm 10.1, \mathrm{p}<0.05$ and $15.4 \pm 5.7, \mathrm{p}<0.05)$. With $10 \mu \mathrm{M}$ tamoxifen 49 genes were observed to be regulated. Figure 7 shows the intersection of expression patterns of black cohosh, E2 and tamoxifen. Among a total of 39 genes that were regulated both under black cohosh and E2 treatment, 30 transcripts were affected in opposite directions (anti-correlated). In contrast, a comparison of black cohosh and tamoxifen revealed a correlated regulation of 32 transcripts. This is quite surprising given that only 49 genes were considered regulated in response to tamoxifen. Hence, the expression profile of black cohosh was more related to tamoxifen. Since E2 stimulated and tamoxifen inhibited proliferation of MCF-7 cells in our assay, it was not surprising that most genes in the intersections are related to cell cycle regulation and apoptosis. 


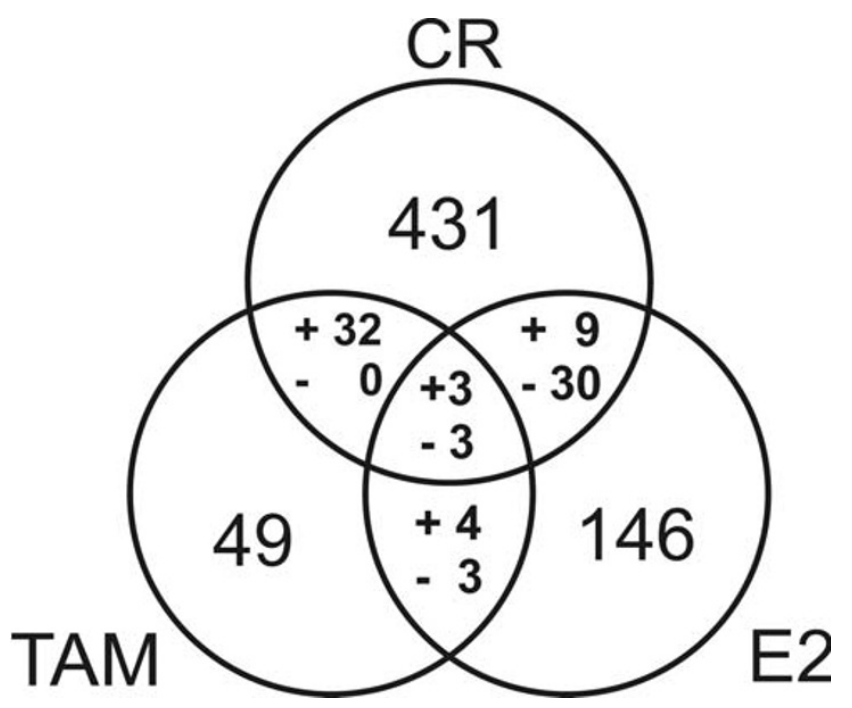

Figure 7

Overlap of expression profiles. Numbers within the 3 circles represent the genes that were differentially expressed according to our filters after $24 \mathrm{~h}$ treatment of MCF-7 cells with Cimicifuga racemosa (black cohosh) extract (CR), I7 $\beta$ estradiol (E2) or tamoxifen (TAM). Numbers within the intersections represent genes regulated with both of the respective treatments or - in the middle - all 3 different treatments. For every intersection genes regulated in the same direction up or down (correlated) are marked with (+). Genes regulated in opposite directions (anti-correlated) are marked with (-).

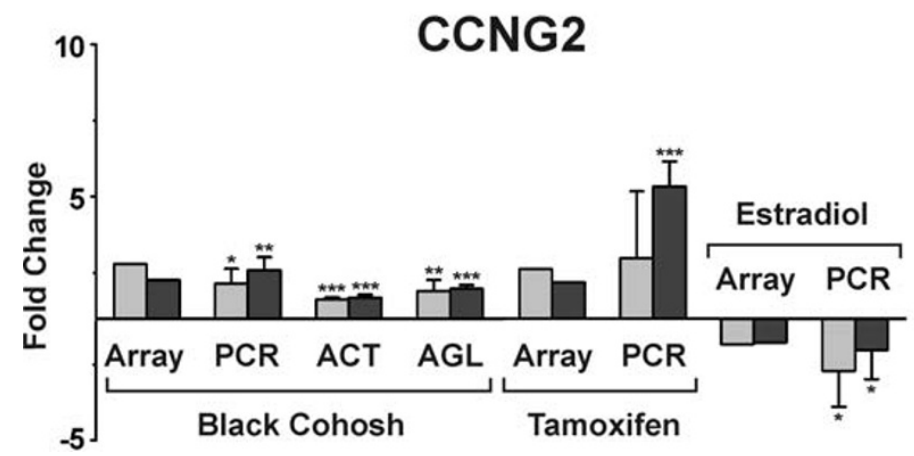

Among the genes associated with cell cycle arrest and apoptosis that were regulated in all treatments, the two cell cycle inhibitory transcripts cyclin G2 (Figure 8) and tumor protein p53 inducible nuclear protein 1 (TP53INP1) were both upregulated by black cohosh and tamoxifen and downregulated by E2. Apart from ESR1, which was downregulated with E2 and black cohosh treatment (Figure 8 ), and VEGF, which can be considered to be regulated via hypoxia response pathways, no gene affected by black cohosh is known to contain estrogen responsive elements (ERE) in the promoter region.

\section{Effects of actein and the cycloartane aglycon mixture}

To identify active principles in black cohosh, MCF-7 cells were treated with the major cycloartane glycoside actein and a mixture of cycloartenol aglycons under the same conditions as in the microarray experiments, at concentrations corresponding to the $\mathrm{IC}_{50}$ values determined in the proliferation assay. We used real-time RT-PCR to determine the expression levels $v$ s. DMSO control of the 13 genes selected on the basis of the microarray experiments: baculoviral IAP repeat-containing 5 (BIRC5), cyclin E2 (CCNE2), cyclin G2 (CCNG2), cytochrome P450 1A1 (CYP1A1), cytochrome P450 1B1 (CYP1B1), DNA-damageinducible transcript 4 (DDIT4), DnaJ (Hsp40) homolog, subfamily B, member 9 (DNAJB9), E2F transcription factor 2 (E2F2), estrogen receptor $\alpha$ (ESR1), growth arrest and DNAdamage-inducible, alpha (GADD45A), metastasis associated in lung adenocarcinoma transcript 1 (MALAT-1), proliferating cell nuclear antigen (PCNA) and vascular endothelial growth factor (VEGF). Upon treatment with actein and the aglycon mixture, all transcripts appeared to be regulated in the same direction and, in a majority of cases, in a compara-

Figure 8

Gene expression levels of cyclin G2 (CCNG2) and estradiol receptor $\alpha$ (ESRI) in MCF-7 cells after $24 \mathrm{~h}$ treatment with black cohosh extract $(I 5 \mu \mathrm{g} / \mathrm{ml})$, the triterpene glycoside actein $(20 \mu \mathrm{M})$, the triterpene aglycon mixture $(30 \mu \mathrm{M})$, tamoxifen $($ I0 $\mu \mathrm{M})$ and estradiol (I nM). For the treatments with extract, tamoxifen and estradiol, results obtained with microarrays (Array) and real-time RT-PCR (PCR) are shown. For actein (ACT) and the aglycons (AGL) expression levels were determined by realtime RT-PCR. Bars represent gene expression levels as fold changes calculated versus DMSO control. RT-PCR measurements were done at least in triplicate. The data are presented as means \pm SD $\left(*_{p}<0.05, *_{p}<0.01\right.$, *** $*_{p}<0.001$ : gene expression statistically significantly different from DMSO control, calculated by Student's t-test). 
ble order of magnitude as with black cohosh treatment (Figures 8 and 9). In general, treatment with actein resulted in a slightly weaker regulation of the expression levels than treatment with the black cohosh extract. In contrast, the treatment with the aglycon mixture caused a marginally stronger up- or downregulation of some genes, such as CCNE2, DNAJB9, E2F2, ESR1 and GADD45A. Also the AhR target genes CYP1A1 and CYP1B1 were upregu-
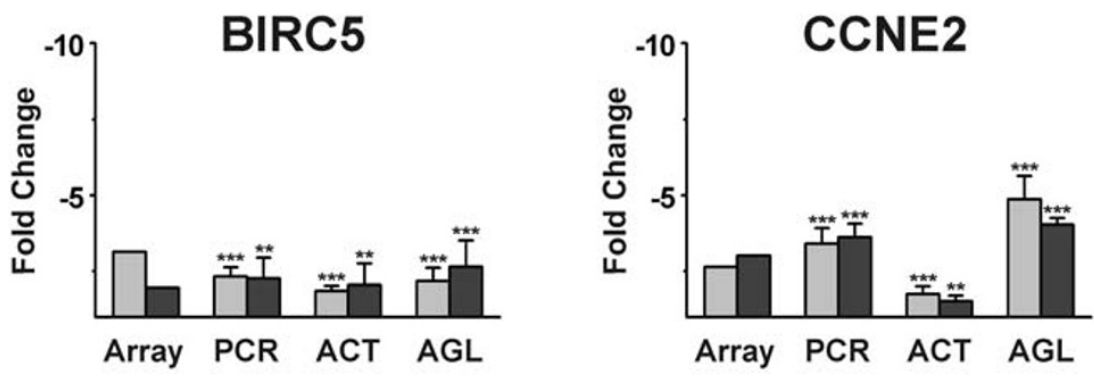
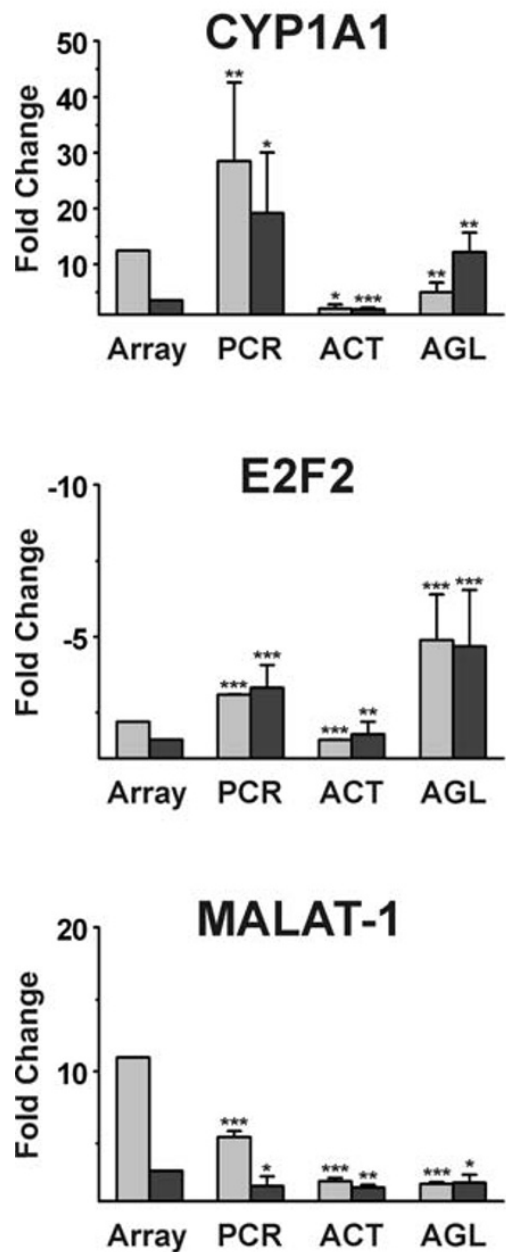
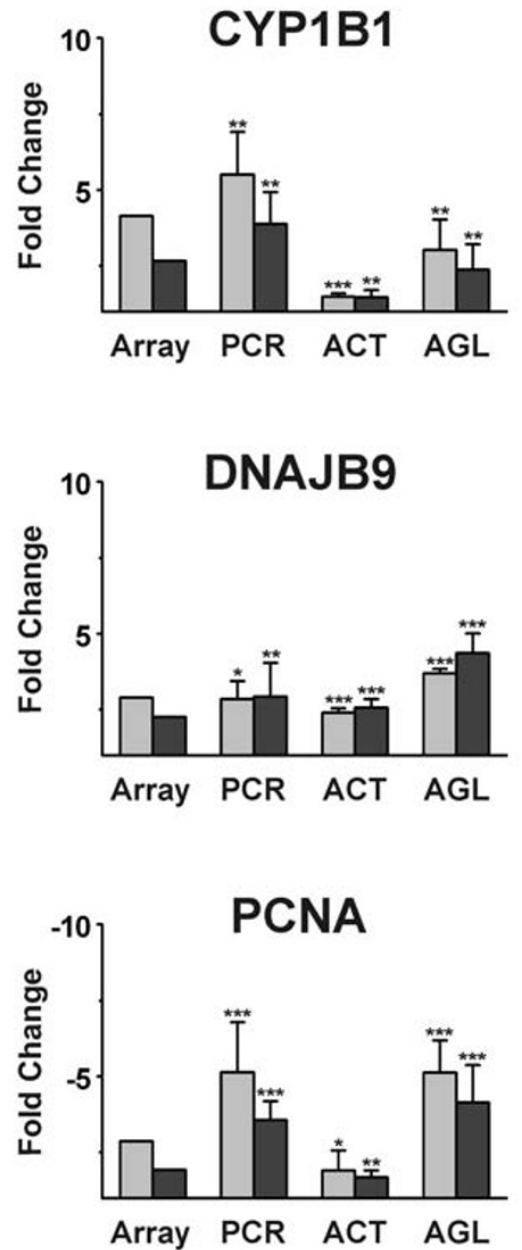
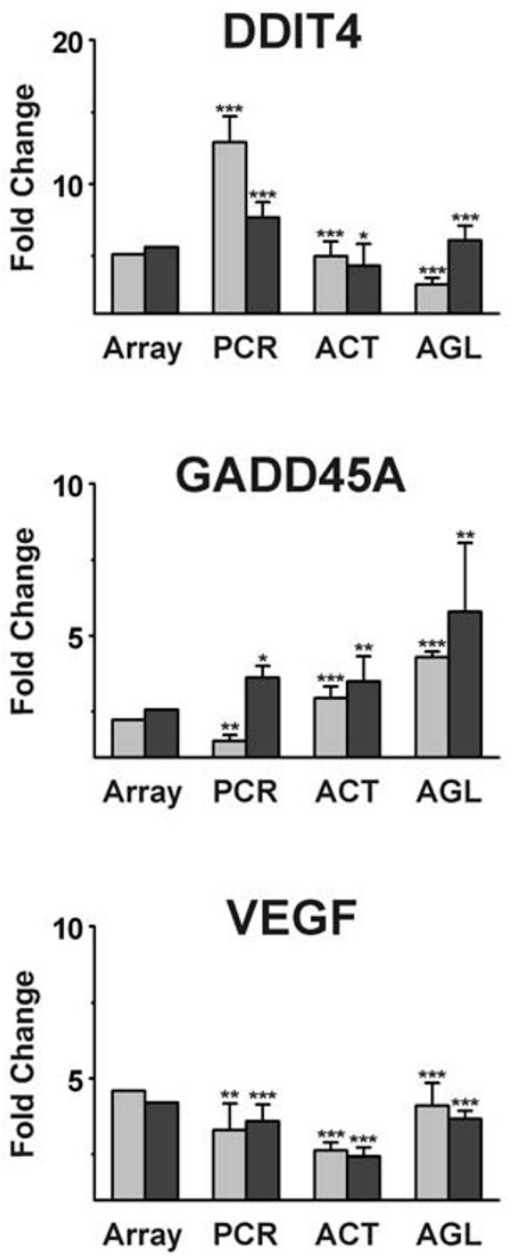

Figure 9

Gene expression levels of selected genes in MCF-7 cells after $24 \mathrm{~h}$ treatment with black cohosh extract (I5 $\mu \mathrm{g} / \mathrm{ml})$, the triterpene glycoside actein $(20 \mu \mathrm{M})$ or the triterpene aglycon mixture $(30 \mu \mathrm{M})$. For extract treatment results obtained with microarrays (Array) and real-time RT-PCR (PCR) are shown. For actein (ACT) and the aglycons (AGL) expression levels were determined by real-time RT-PCR. Bars represent gene expression levels as fold changes calculated versus DMSO control. RTPCR measurements were done at least in triplicate. The data are presented as means \pm SD $\left(*_{p}<0.05, *^{*} p<0.01\right.$, $* * * p<0.001$ : gene expression statistically significantly different from DMSO control, calculated by Student's t-test). 
lated by the aglycon mixture and with actein albeit at a lower level.

\section{Discussion}

We performed the first gene expression profiling experiment with rhizomes of Cimicifuga racemosa (black cohosh) to identify molecular effects in the human breast cancer cell line MCF-7. In initial experiments analyzing cell proliferation we observed growth inhibition in response to treatment with a lipophilic extract of black cohosh, the major cycloartane-type triterpene glycoside actein and a cycloartane aglycon mixture. $\mathrm{IC}_{50}$ values were comparable to previously reported results [22-24].

Effects of a black cohosh extract on gene expression in MCF-7 cells were determined by means of Affymetrix GeneChip ${ }^{\circledR}$ Human Genome U133 Plus 2.0 arrays, enabling almost complete analysis of the transcriptome. After treatment of MCF-7 cells for $24 \mathrm{~h}$ with the black cohosh extract at the $\mathrm{IC}_{50}$ concentration $(15 \mu \mathrm{g} / \mathrm{ml})$ changes of the expression levels of 431 genes were detected using highly stringent selection criteria. Random permutation of gene expression profiles showed a mean of 22 to 32 regulated probe sets in our data set with our selection criteria indicating a false positive rate of about $5 \%$.

Comparing the expression patterns, action of black cohosh is opposite to estradiol and more similar to tamoxifen regarding proliferation and cell survival. However, the effect of black cohosh treatment appears more complex, as significantly more genes were regulated than either with E2 or tamoxifen. The genes regulated by black cohosh did not include well-known estrogen-regulated genes, with the exception of ESR1 (the estrogen recptor $\alpha$ gene) and VEGF which both could be regulated via hypoxia response. In contrast, a wider range of cellular pathways and targets were affected by black cohosh but not E2 or tamoxifen. Hence, action of black cohosh in MCF-7 cells seems to be neither estrogenic nor antiestrogenic but rather multifacetted. Because MCF-7 is a model for determining estrogenic or antiestrogenic effects, we can conclude that the benefical effects of black cohosh in alleviating postmenopausal complaints might be rather due to central nervous action via dopamine, serotonin or $\mu$ opioidic receptors.

Among all regulated genes, those related to the functional categories of proliferation (cell cycle and DNA replication) and stress response (including members of different functional categories) were found to be highly significantly overrepresented, and these groups appear to be interconnected. Given that many genes were regulated at a lower level and, therefore, excluded by the stringent filter setting, a statistically highly significant accumulation of genes in these functional categories emphasizes the significance of our results.

The cell cycle inhibition observed in the proliferation experiments appears to be due to an arrest at both G1/Sand G2/M-transition points, as indicated by an accumulation of regulated genes. This finding is corroborated by recent results of a flow cytometric analysis [24]. Several genes involved in apoptosis appeared to be regulated, most genes in a pro-apoptotic manner. Some genes are related to apoptotic as well as anti-apoptotic events. These genes are linked to different cellular stress response mechanisms. Altogether, the expression levels of approximatively 40 genes related to stress response were affected by black cohosh. Given the fact that results of stress response pathways are contradictory, pro- and anti-apoptotic gene expression may not be surprising. The main purpose of stress response is an adaptation of the cells to stress factors, resulting in cell survival, angiogenesis and promoted tumor growth. However, when stress reaches a certain threshold, the protecting pathways become saturated and cells undergo apoptosis [49]. This may explain the seemingly contradictory effects observed in our experiment. Altogether, pro-apoptotic signalling seems to outweigh. Stress response regulation has already been previously reported for other xenobiotics such as the cancer chemoprotective phytochemical indole-3-carbinol (I3C) and its physiological condensation product diindolylmethane (DIM), whose antitumor activity has been widely investigated [42]. Its influence on gene expression in different tumor cells - among others in breast cancer cells such as MCF-7 - shows a certain similarity to our results with black cohosh. However, the mechanism of induced stress response by $\mathrm{I} 3 \mathrm{C}$ is still unknown.

In association with unfolded protein response various transcripts of protein turnover were affected by black cohosh. Regulation of several transcripts whose products are involved in ubiquitinylation may be due to augmented degradation of malformed proteins. Increased mRNA levels of not less than eight different aminoacyltRNA synthetases (ARSs) are not only linked to protein synthesis. Some ARSs are rather multifunctional proteins involved in different cellular processes [61]. For example, the secretion of tyrosyl-tRNA synthetase (YARS) is linked to apoptotic events [39] and tryptophanyl-tRNA synthetase (WARS) has been shown to possess angiostatic and proliferation-inhibitory activity [61].

As response to exposure to black cohosh extract a group of transcripts coding for enzymes with oxidoreductase activity was upregulated ("response to xenobiotics"). A strong upregulation was observed for CYP1A1, and, to a somewhat lesser extent, of CYP1B1. Apart from well-known involvement in xenobiotic metabolism, thereby mediat- 
ing toxic and tumorigenic effects of several chemicals, these two oxidoreductases are involved in the metabolism of 17ß-estradiol [62]. CYP1A1 metabolizes E2 to non-carcinogenic 2-hydroxy-E2 whereas CYP1B1 is responsible for the formation of carcinogenic 4-hydroxy-E2. The two enzymes are not always expressed at the same level in tissues. An increased production of 2-hydroxy-E2 relative to 4-hydroxy-E2, due to a higher expression level of CYP1A1 than CYP1B1, has been suggested to be contributing to the antitumor activity of indol-3-carbinol and, therefore, being of clinical importance [62]. As described, we also observed significantly stronger induction of CYP1A1 transcripts than CYP1B1 with black cohosh treatment.

CYP1A1 is known as the classical target of the aryl hydrocarbon receptor (AhR). Interestingly, the receptor has also been upregulated with our experiment. The AhR, upon binding of a ligand, forms a heterodimeric complex with ARNT (aryl hydrocarbon receptor nuclear translocator) which induces transactivation of the CYPs and other target genes via binding to xenobiotic response elements (XREs) in their promoter regions [63]. Classical AhR ligands and, therefore, CYP1A1 inducers are hydrophobic and planar or coplanar molecules of polycyclic structure. Although the cycloartane-type triterpenoids do not satisfy these structural requirements, gene expression of CYP1A1 was not only induced in our experiments by black cohosh extract but also by the cycloartane aglycons $(5.0 \pm 1.7$ fold, $\mathrm{p}<0.01$ and $12.2 \pm 3.4$ fold, $\mathrm{p}<0.01)$ and, to a lower but statistically significant extent, by actein $(2.1 \pm 0.8, \mathrm{p}<0.05$ and $2.0 \pm 0.2, \mathrm{p}<0.01)$. CYP1B1 was also differentially expressed by the triterpenoids. The upregulation of CYP1A1 and CYP1B1 expression by extract and purified cycloartanes cannot be explained by AhR binding. Indeed, black cohosh extract and compounds did not show any AhR activity in a reporter gene assay [64] in rat hepatoma H4IIE cells [see Additional file 2]. These findings are in contradiction with previous experiments showing weak AhR binding and transactivation activity of black cohosh extracts. However, these experiments were carried out with high concentrations (up to $200 \mu \mathrm{g} / \mathrm{ml}$ ) and did not include single compounds $[20,21]$. The upregulation of CYP1A1 and CYP1B1 may be linked to activation of genes involved with hypoxic stress response, although the consequences of upregulated stress response appear somewhat contradictory. AhR and hypoxia-induced signal transduction are connected via ARNT, and AhR and HIF1 $\alpha$ compete in binding to ARNT. Hypoxic conditions reportedly inhibited AhR-dependent gene expression [65], on the other hand, a connection between CYP1A1 induction and hypoxia-induced gene regulation in $\mathrm{Caco} 2$ cells has been found [66].

Besides CYP1A1 and CYP1B1, 11 other selected mRNAs representing all regulated functional categories were investigated by real-time RT-PCR to verify the microarray results and to investigate the effects of the cycloartanetype triterpenoids. Briefly, all genes were regulated by the triterpenoids in the same direction and to a fairly comparable extent than with the extract. Hence, we provide here first evidence that cycloartane glycosides as well as their aglycons, which are most likely formed in the intestine prior to absorption, are putative active principles in black cohosh.

\section{Conclusion}

In conclusion, the microarray investigation on black cohosh in MCF-7 breast cancer cells revealed several new interesting aspects. Gene expression "contra cell proliferation" and "pro apoptosis" emphasizes previously reported actions of black cohosh. These effects might be a result of stress response to hypoxic conditions, protein disturbances and induction of oxidoreductases, evoked by an exposure to black cohosh extract. Regulation of other genes, eg. induction of CYP1A1, IFNGR1 and WARS and downregulation of ER $\alpha$ mRNA (ESR1) might contribute to a putative antitumor activity of black cohosh. On the other hand, activation of genes involved in cell survival, angiogenesis and tumor progression, such as VEGF, S100P, MALAT-1 and different stress response genes, raises questions. Since black cohosh is increasingly popular as an alternative to HRT, a thorough benefit/risk assessment is required. Black cohosh preparations have been considered as safe up to now and no serious adverse reactions have been reported so far. Nonetheless, further investigations are needed to assess the safety level and to analyze putative antitumor applications with functional assays and in vivo models.

\section{Competing interests}

The author(s) declare that there are no competing interests.

\section{Authors' contributions}

$\mathrm{MH}$ and SW conceived the study and supervised its performance. FG carried out all experiments with the exception of RNA isolation and the following steps of the microarray experiment which were performed by LP. Data analysis was performed by TK, FG and SW. FG and SW drafted the manuscript and MH participated in its preparation. All authors have read and approved the manuscript. 


\section{Additional material}

\section{Additional file 1}

Differentially expressed genes. The table lists all 431 genes differentially expressed ( $>1.5$ fold in two parallel experiments) by black cohosh extract in MCF-7 cells.

Click here for file

[http://www.biomedcentral.com/content/supplementary/1471-

2210-7-11-S1.pdf]

\section{Additional file 2}

Aryl hydrocarbon receptor activity. The diagram presents the results of a XRE-dependent reporter gene assay in rat H4IIE cells.

Click here for file

[http://www.biomedcentral.com/content/supplementary/14712210-7-11-S2.pdf]

\section{Acknowledgements}

We are very grateful to Dr. Joachim Clement, Clinic of Internal Medicine II, University of Jena, Germany, for providing the MCF-7 cells and the LightCycler ${ }^{\circledR}$ PCR system, and to Prof. Dr. Dieter Schrenk, Annette Baumgart and Dr. Hans-Joachim Schmitz, Division of Food Chemistry/Toxicology, University of Kaiserslautern, Germany, for performing the AhR reporter gene assay.

\section{References}

I. Liske E: Therapeutic efficacy and safety of Cimicifuga racemosa for gynecologic disorders. Adv Ther 1998, 15:45-53.

2. Borrelli $F$, Ernst E: Cimicifuga racemosa: a systematic review of its clinical efficacy. Eur J Clin Pharmacol 2002, 58:235-24I.

3. Mahady GB: Black cohosh (Actaea/Cimicifuga racemosa) Review of the clinical data for safety and efficacy in menopausal symptoms. Treat Endocrinol 2005, 4: 177-184.

4. Writing Group for the Women's Health Initiative Investigators: Risks and benefits of estrogen plus progestin in healthy postmenopausal women: Principal results from the Women's Health Initiative randomized controlled trial. JAMA 2002, 288:32I-333.

5. Kruse SO, Lohning A, Pauli GF, Winterhoff H, Nahrstedt A: Fukiic and piscidic acid esters from the rhizome of Cimicifuga racemosa and the in vitro estrogenic activity of fukinolic acid. Planta Med 1999, 65:763-764.

6. Jarry $\mathrm{H}$, Harnischfeger $\mathrm{G}$ : Endocrine effects of constituents of Cimicifuga racemosa: I. The effect on serum levels of pituitary hormones in ovariectomized rats. Planta Med 1985, 5 I:46-49.

7. Jarry $H$, Harnischfeger $G$, Duker $E$ : The endocrine effects of constituents of Cimicifuga racemosa: 2 . In vitro binding of constituents to estrogen receptors. Planta Med 1985, $51: 316-319$.

8. Borrelli F, Izzo AA, Ernst E: Pharmacological effects of Cimicifuga racemosa. Life Sci 2003, 73:1215-1229.

9. Einer-Jensen N, Zhao J, Andersen KP, Kristoffersen K: Cimicifuga and Melbrosia lack oestrogenic effects in mice and rats. Maturitas 1996, 25: I49-153.

10. Liu J, Burdette JE, Xu H, Gu C, van Breemen RB, Bhat KP, Booth N, Constantinou Al, Pezzuto JM, Fong HH, Farnsworth NR, Bolton JL: Evaluation of estrogenic activity of plant extracts for the potential treatment of menopausal symptoms. J Agric Food Chem 200I, 49:2472-2479.

II. Stromeier S, Petereit F, Nahrstedt A: Phenolic esters from the rhizomes of Cimicifuga racemosa do not cause proliferation effects in MCF-7 cells. Planta Med 2005, 71:495-500.

12. Bodinet C, Freudenstein J: Influence of Cimicifuga racemosa on the proliferation of estrogen receptor-positive human breast cancer cells. Breast Cancer Res Treat 2002, 76: 1-10.
13. Zierau O, Bodinet C, Kolba S, Wulf M, Vollmer G: Antiestrogenic activities of Cimicifuga racemosa extracts. J Steroid Biochem Mol Biol 2002, 80:125-130.

14. Wuttke W, Seidlov $\alpha$-Wuttke D, Gorkow C: The Cimicifuga preparation BNO 1055 vs. conjugated estrogens in a double-blind placebo-controlled study: Effects on menopause symptoms and bone markers. Maturitas 2003, 44:S67-S77.

15. Seidlov $\alpha$-Wuttke D, Hesse O, Jarry H, Christoffel V, Spengler B, Becker T, Wuttke W: Evidence for selective estrogen receptor modulator activity in a black cohosh (Cimicifuga racemosa) extract: Comparison with estradiol-I 7beta. Eur J Endocrinol 2003, |49:35I-362.

16. Jarry $\mathrm{H}$, Metten $\mathrm{M}$, Spengler $\mathrm{B}$, Christoffel $\mathrm{V}$, Wuttke $\mathrm{W}$ : In vitro effects of the Cimicifuga racemosa extract BNO 1055. Maturitas 2003, 44:S3I-S38.

17. Viereck V, Emons G, Wuttke W: Black cohosh: just another phytoestrogen? Trends Endocrinol Metab 2005, 16:2| 4-221.

18. Zava DT, Dollbaum CM, Blen M: Estrogen and progestin bioactivity of foods, herbs, and spices. Proc Soc Exp Biol Med 1998, 217:369-78.

19. Beck V, Unterrieder E, Krenn L, Kubelka W, Jungbauer A: Comparison of hormonal activity (estrogen, androgen and progestin) of standardized plant extracts for large scale use in hormone replacement therapy. J Steroid Biochem Mol Biol 2003, 84:259-268.

20. Jeuken A, Keser BJ, Khan E, Brouwer A, Koeman J, Denison MS: Activation of the Ah receptor by extracts of dietary herbal supplements, vegetables, and fruits. J Agric Food Chem 2003, $5 \mathrm{I}: 5478-5487$.

21. Jarry H, Thelen P, Christoffel V, Spengler B, Wuttke W: Cimicifuga racemosa extract BNO 1055 inhibits proliferation of the human prostate cancer cell line LNCaP. Phytomedicine 2005, I 2:178-182.

22. Hostanska K, Nisslein T, Freudenstein J, Reichling J, Saller R: Cimicifuga racemosa extract inhibits proliferation of estrogen receptor-positive and negative human breast carcinoma cell lines by induction of apoptosis. Breast Cancer Res Treat 2004, 84: $15 I-160$.

23. Hostanska K, Nisslein T, Freudenstein J, Reichling J, Saller R: Evaluation of cell death caused by triterpene glycosides and phenolic substances from Cimicifuga racemosa extract in human MCF-7 breast cancer cells. Biol Pharm Bull 2004, 27: 1970-1975.

24. Einbond LS, Shimizu M, Xiao D, Nuntanakorn P, Lim JT, Suzui M, Seter C, Pertel T, Kennelly EJ, Kronenberg F, Weinstein IB: Growth inhibitory activity of extracts and purified components of black cohosh on human breast cancer cells. Breast Cancer Res Treat 2004, 83:22I-23I.

25. Lohning A, Verspohl EJ, Winterhoff $\mathrm{H}$ : Pharmacological studies on the dopaminergic activity of Cimicifuga racemosa. Paper presented at the 23rd Int LOF-Symposium on Phytoestrogens, University of Gent, Belgium I5th January 1999.

26. Burdette JE, Liu J, Chen SN, Fabricant DS, Piersen CE, Barker EL, Pezzuto JM, Mesecar A, Van Breemen RB, Farnsworth NR, Bolton JL: Black cohosh acts as a mixed competitive ligand and partial agonist of the serotonin receptor. J Agric Food Chem 2003, 51:5661-5670.

27. Fabricant DS, Nikolic D, Lankin DC, Chen SN, Jaki BU, Krunic A, van Breemen RB, Fong HH, Farnsworth NR, Pauli GF: Cimipronidine, a cyclic guanidine alkaloid from Cimicifuga racemosa. J Nat Prod 2005, 68: | 266- I 270 .

28. Rhyu MR, Lu J, Webster DE, Fabricant DS, Farnsworth NR, Wang Z]: Black cohosh (Actaea racemosa, Cimicifuga racemosa) behaves as a mixed competitive ligand and partial agonist at the human $\mu$ opiate receptor. J Agric Food Chem 2006, 54:9852-9857.

29. Mosmann T: Rapid colorimetric assay for cellular growth and survival: Application to proliferation and cytotoxicity assays. J Immunol Meth 1983, 65:55-63.

30. Denizot F, Lang R: Rapid colorimetric assay for cellular growth and survival: Modifications to the tetrazolium dye procedure giving improved sensivity and reliability. J Immunol Meth 1986, 89:27I-277.

3I. RMAExpress, release $\mathbf{0 . 5}$ [http://rmaexpress.bmbolstad.com]

32. Bolstad BM, Irizarry RA, Astrand M, Speed TP: A comparison of normalization methods for high density oligonucleotide array data based on bias and variance. Bioinformatics 2003, 19:185-193. 
33. Irizarry RA, Bolstad BM, Collin F, Cope LM, Hobbs B, Speed TP. Summaries of Affymetrix GeneChip probe level data. Nucleic Acids Res 2003, 3 I:el 5.

34. Villalobos M, Olea N, Brotons JA, Olea-Serrano MF, Ruiz de Almodovar JM, Pedraza V: The E-screen assay: a comparison of different MCF7 cell stocks. Environ Health Perspect 1995, I 03:844-850.

35. Tian CY, Hu CQ, Xu G, Song HY: Assessment of estrogenic activity of natural compounds using improved E-screen assay. Acta Pharmacol Sin 2002, 23:572-576.

36. NetAffx ${ }^{\mathrm{TM}}$ Analysis Center [http://www.affymetrix.com/analysis/ index.affx]

37. Gene Expression Omnibus [http://www.ncbi.nlm.nih.gov/geo/]

38. GenMAPP [http://www.genmapp.org]

39. Wakasugi K, Schimmel P: Two distinct cytokines released from a human aminoacyl-tRNA synthetase. Science 1999 284:|47-|5|.

40. Raabe EH, Abdurrahman L, Behbehani G, Arceci RJ: An SNF2 factor involved in mammalian development and cellular proliferation. Dev Dyn 2001, 22 I:92-105.

41. Ron D: Translational control in the endoplasmic reticulum stress response. J Clin Invest 2002, I I 0: 1383- I388.

42. Sun S, Han J, Ralph WM Jr, Chandrasekaran A, Liu K, Auborn KJ, Carter TH: Endoplasmic reticulum stress as a correlate of cytotoxicity in human tumor cells exposed to diindolylmethane in vitro. Cell Stress Chaperones 2004, 9:76-87.

43. Shoshani T, Faerman A, Mett I, Zelin E, Tenne T, Gorodin S, Moshel Y, Elbaz S, Budanov A, Chajut A, Kalinski H, Kamer I, Rozen A, Mor $O$, Keshet E, Leshkowitz D, Einat P, Skaliter R, Feinstein E: Identification of a novel hypoxia-inducible factor I-responsive gene, RTP80I, involved in apoptosis. Mol Cell Biol 2002, 22:2283-2293.

44. Wu MX: Roles of the stress-induced gene IEX-I in regulation of cell death and oncogenesis. Apoptosis 2003, 8: I I-I8.

45. Path G, Opel A, Knoll A, Seufert J: Nuclear protein $\mathbf{p} 8$ is associated with glucose-induced pancreatic beta-cell growth. Diabetes 2004, 53:S82-85

46. Ito Y, Yoshida H, Motoo Y, lovanna JL, Nakamura Y, Kakudo K, Uruno T, Takamura Y, Miya A, Noguchi S, Kuma K, Miyauchi A: Expression of p8 protein in breast carcinoma: an inverse relationship with apoptosis. Anticancer Res 2005, 25:833-837.

47. Harris AL: Hypoxia - a key regulatory factor in tumour growth. Nat Rev Cancer 2002, 2:38-47.

48. Patil C, Walter P: Intracellular signaling from the endoplasmic reticulum to the nucleus: the unfolded protein response in yeast and mammals. Curr Opin Cell Biol 200I, I 3:349-355.

49. Feldman DE, Chauhan V, Koong AC: The unfolded protein response: a novel component of the hypoxic stress response in tumors. Mol Cancer Res 2005, 3:597-605.

50. Watowich SS, Morimoto RI: Complex regulation of heat shockand glucose-responsive genes in human cells. Mol Cell Biol 1988, 8:393-405.

51. Fafournoux $P$, Bruhat $A$, Jousse $C$ : Amino acid regulation of gene expression. Biochem J 2000, 35 I:I-I2.

52. Wouters BG, van den Beucken T, Magagnin MG, Koritzinsky M, Fels $D$, Koumenis $C$ : Control of the hypoxic response through regulation of mRNA translation. Semin Cell Dev Biol 2005 , I 6:487-50|.

53. Cummins EP, Taylor CT: Hypoxia-responsive transcription factors. Pfluegers Arch Eur J Physiol 2005, 450:363-37I.

54. Budanov AV, Shoshani T, Faerman A, Zelin E, Kamer I, Kalinski H, Gorodin S, Fishman A, Chajut A, Einat P, Skaliter R, Gudkov AV, Chumakov PM, Feinstein E: Identification of a novel stress-responsive gene $\mathrm{Hi95}$ involved in regulation of cell viability. Oncogene 2002, 2 l:6017-6031.

55. Kim R, Emi M, Tanabe K, Murakami S: Role of the unfolded protein response in cell death. Apoptosis 2006, I I:5-I3.

56. Kokame K, Agarwala KL, Kato H, Miyata T: Herp, a new ubiquitinlike membrane protein induced by endoplasmic reticulum stress. J Biol Chem 2000, 275:32846-32853.

57. Kurebayashi J, Otsuki T, Moriya T, Sonoo H: Hypoxia reduces hormone responsiveness of human breast cancer cells. Ipn / Cancer Res 2001, 92:1093-I101.

58. Ikeda H, Old LJ, Schreiber RD: The roles of IFN gamma in protection against tumor development and cancer immunoediting. Cytokine Growth Factor Rev 2002, 13:95-109.

59. Ji P, Diederichs S, Wang W, Boing S, Metzger R, Schneider PM, Tidow $N$, Brandt B, Buerger H, Bulk E, Thomas M, Berdel WE, Serve H,
Muller-Tidow C: MALAT-I, a novel noncoding RNA, and thymosin beta4 predict metastasis and survival in early-stage non-small cell lung cancer. Oncogene 2003, 22:803 I-804I.

60. Russo J, Hu YF, Silva ID, Russo IH: Cancer risk related to mammary gland structure and development. Microsc Res Tech 200 I, 52:204-223.

61. Ko YG, Park H, Kim S: Novel regulatory interactions and activities of mammalian tRNA synthetases. Proteomics 2002, 2:1304-1310.

62. Dalton TP, Puga A, Shertzer HG: Induction of cellular oxidative stress by aryl hydrocarbon receptor activation. Chem Biol Interact 2002, | 4 |:77-95.

63. Delescluse C, Lemaire G, de Sousa G, Rahmani R: Is CYPIAI induction always related to AHR signaling pathway? Toxicology 200I, I 53:73-82

64. Baumgart A, Schmidt M, Schmitz HJ, Schrenk D: Natural furanocoumarins as inducers and inhibitors of cytochrome $\mathbf{P 4 5 0}$ IAI in rat hepatocytes. Biochem Pharmacol 69:657-667.

65. Chan WK, Yao G, Gu YZ, Bradfield CA: Cross-talk between the aryl hydrocarbon receptor and hypoxia inducible factor sig. naling pathways. Demonstration of competition and compensation. J Biol Chem 1999, 274: I21 I5-12123.

66. Carriere V, Rodolosse A, Lacasa M, Cambier D, Zweibaum A, Rousset $M$ : Hypoxia and CYPIAI induction-dependent regulation of proteins involved in glucose utilization in Caco-2 cells. Am J Physiol 1998, 274:GI I0I-I I08.
Publish with Bio Med Central and every scientist can read your work free of charge

"BioMed Central will be the most significant development for disseminating the results of biomedical research in our lifetime. "

Sir Paul Nurse, Cancer Research UK

Your research papers will be:

- available free of charge to the entire biomedical community

- peer reviewed and published immediately upon acceptance

- cited in PubMed and archived on PubMed Central

- yours - you keep the copyright

Submit your manuscript here:

http://www.biomedcentral.com/info/publishing_adv.asp
BioMedcentral 